Discussion Paper No. 10-083

\title{
Airline Alliances, Antitrust Immunity and Market Foreclosure
}

Volodymyr Bilotkach and Kai Hüschelrath

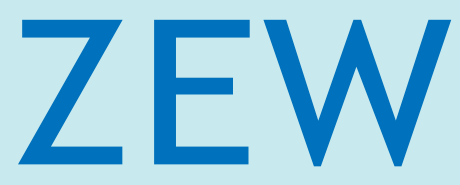

Zentrum für Europäische Wirtschaftsforschung $\mathrm{GmbH}$

Centre for European

Economic Research 
Discussion Paper No. 10-083

\title{
Airline Alliances, Antitrust Immunity and Market Foreclosure
}

\author{
Volodymyr Bilotkach and Kai Hüschelrath
}

Download this ZEW Discussion Paper from our ftp server:

ftp://ftp.zew.de/pub/zew-docs/dp/dp10083.pdf

Die Discussion Papers dienen einer möglichst schnellen Verbreitung von neueren Forschungsarbeiten des ZEW. Die Beiträge liegen in alleiniger Verantwortung der Autoren und stellen nicht notwendigerweise die Meinung des ZEW dar.

Discussion Papers are intended to make results of ZEW research promptly available to other economists in order to encourage discussion and suggestions for revisions. The authors are solely responsible for the contents which do not necessarily represent the opinion of the ZEW. 


\section{Non-technical summary}

The development of international airline markets has led to the dominance of three global airline alliances - Star, SkyTeam and oneworld. As part of an overall assessment of the competitive effects of such agreements, the theoretical literature has suggested that members of an international airline partnership might have an incentive to foreclose the beyond-the-gateway markets to the airlines excluded from the respective alliance. It has also been suggested that such foreclosure will likely be most effective when alliance partners have the right to jointly set fares for the interline services, and engage in revenue sharing arrangements - a privilege otherwise known as antitrust immunity. This paper analyzes and quantifies effects of such market foreclosure.

We conduct an extensive analysis of the data on non-stop services on the transatlantic scheduled commercial passenger airline market. Merging the data with the information on the structure of the airlines' networks and dynamics of the airline partnerships on the same market over the time period from 1992 to 2008, we are able to analyze whether the airlines enjoying antitrust immunity take steps to exclude interline passengers arriving on the rival carriers' flights. We find that antitrust immunity leads to a 2.5-6 percent $(0.7-$ 1.5 percent in dynamic panel data GMM estimation) decrease in frequency of service by the non-alliance carriers serving a newly immunized hub. The effect on the passenger volumes is even greater (4.8 to 8.5 percent drop in fixed effects, 2.6 to 3.5 percent in GMM; and generally 1.5 to 2 times the effect on frequency). This suggests that excluded airlines switch to smaller aircrafts and/or end up with lower load factors on their services to the newly immunized hubs. We also find evidence (less robust, however) that antitrust immunity may lead to lower passenger volumes on routes between the competing alliances' hubs. 


\section{Das Wichtigste in Kürze}

Die Marktentwicklungen im internationalen Luftverkehr haben zur Dominanz dreier großer und global agierender Allianzen von Fluggesellschaften geführt - Star, SkyTeam und oneworld. Als Teil einer ganzheitlichen Untersuchung der wettbewerblichen Effekte solcher Allianzen hat die theoretische Literatur die Hypothese aufgestellt, dass die Mitglieder einer solchen Allianz möglicherweise einen Anreiz haben, Märkte für Zubringerflüge für Fluggesellschaften $\mathrm{zu}$ verschließen, die nicht Mitglied in der jeweiligen Allianz sind. In diesem Zusammenhang wird auch behauptet, dass die Implementierung solcher Abschottungsstrategien dann am effektivsten ist, wenn die Allianzmitglieder die Preise der Interline-Verbindungen absprechen und die dadurch generierten Umsätze untereinander aufteilen dürfen - also Antitrust-Immunität genießen. Dieser Aufsatz analysiert und quantifiziert die Effekte einer solchen Form der Abschottung in Luftverkehrsmärkten.

Wir führen eine umfassende empirische Analyse auf Basis von Daten für direkte Linienflüge für Passagiere im transatlantischen Markt zwischen Europa und den USA durch. Durch die Zusammenführung dieser Daten mit Daten zur Struktur der Streckennetze der Fluggesellschaften und der dynamischen Entwicklung der Luftverkehrsallianzen für den Zeitraum von 1992 bis 2008 sind wir in der Lage zu untersuchen, ob die Fluggesellschaften mit Antitrust-Immunität Schritte unternehmen, die Interlining-Passagiere von außenstehenden Fluggesellschaften auszuschließen. Die Ergebnisse der Untersuchung zeigen, dass die Gewährung von Antitrust-Immunität zu einer 2,5-6\%-igen Reduktion der Flugfrequenzen (zu den jeweiligen ,immunisierten Drehkreuzen') derjenigen Fluggesellschaften führt, die nicht der betreffenden Allianz angehören. Der Effekt auf das Passagieraufkommen ist noch deutlicher. Es findet sich ein Rückgang zwischen 4,8\% und 8,5\% bei der ,fixed effects’ Modellierung bzw. zwischen 2,6\% und 3,5\% bei GMM. Grundsätzlich ist der Effekt auf das Passagieraufkommen 1,5 bis 2 Mal stärker als bei den Flugfrequenzen. Die Ergebnisse legen nahe, dass abgeschottete Fluggesellschaften zu kleineren Flugzeugen wechseln oder aber niedrigere Auslastungen ihrer Flüge zu den jeweiligen ,immunisierten Drehkreuzen’ zu verzeichnen haben. Darüber hinaus finden wir (wenn auch schwächere) Belege dafür, dass die Gewährung von Antitrust-Immunität zu einem niedrigeren Passgieraufkommen auf Strecken zwischen im Wettbewerb stehenden Drehkreuzen führt. 


\title{
Airline Alliances, Antitrust Immunity and Market Foreclosure
}

\author{
Volodymyr Bilotkach* and Kai Hüschelrath*
}

\begin{abstract}
This paper examines the issue of market foreclosure by airline partnerships with antitrust immunity. Overlapping the data on frequency of service and passenger volumes on nonstop routes on the transatlantic airline market with the information on dynamics of airline partnerships, we find evidence consistent with the airlines operating under antitrust immunity refusing to accept connecting passengers from the carriers outside of the partnership at respective hub airports. When an airline partnership is granted antitrust immunity, airlines outside this partnership end up reducing their traffic to the partner airlines' hub airports by 2.6-8.5 percent (depending on the specification and estimation technique involved). Our results suggest ambiguous welfare effects of antitrust immunity on some markets, where previous studies indicated airline consolidation should benefit consumers.
\end{abstract}

Keywords: Air transportation, alliances, antitrust immunity, foreclosure JEL Codes: L41, L93, K21

\footnotetext{
* Assistant Professor of Economics, University of California, Irvine, 3151 Social Science Plaza, Irvine, CA 92697, USA, E-Mail: vbilotka@uci.edu. We started working on this project while Bilotkach was a visiting researcher at ZEW. Bilotkach thanks ZEW for support and hospitality. Furthermore, we are indebted to Jan Brueckner, Tobias Veith and Matthias Hunold for detailed comments on previous drafts of the paper and to Leonie Giessing for excellent research assistance.

* Researcher, ZEW Centre for European Economic Research, Department for Industrial Economics and International Management, P.O. Box 1034 43, D-68034 Mannheim, Germany, E-mail: hueschelrath@zew.de; Assistant Professor for Industrial Organization and Competitive Strategy, WHU Otto Beisheim School of Management, Burgplatz 2, 56179 Vallendar, Germany.
} 
"[I]t has become much harder to negotiate good deals for flights from Paris and Frankfurt since immunity was granted.”

Travel manager of a big European Bank (2009) ${ }^{1}$

\section{Introduction}

A crucial feature of the airline industry is that the level of demand on most city-pair markets is not sufficient to sustain regular non-stop services. The airlines' response has been to operate hub-and-spoke networks, channeling passengers via one or several airports (hubs). While in the US domestic airline industry most of the travelers do not have to change the operating carrier en route, the situation is very different on the international markets, where scale and regulatory restrictions do not allow setting up 'mega-airlines' with networks encompassing the entire world. The carriers' response has been to form partnerships to facilitate interline trips by the consumers. A number of such partnerships on the routes originating from the USA operate under 'antitrust immunity', which allows the carriers to jointly make scheduling and pricing decisions on the corresponding joint networks; revenue sharing is also allowed. ${ }^{2}$

International airline partnerships operating under antitrust immunity provide a nice setup for an empirical investigation of market foreclosure - a practice that generally involves denying the actual or potential competitors access to either an essential input or customers, thereby preventing them from competing. Antitrust immunity can lead to market foreclosure, as respective alliance members will be reluctant to accept interline passengers from the outside airlines. In fact, such a concern has been specifically raised by American Airlines - the carrier claimed that it has become more difficult for it to feed its passengers to Air France's flights at Paris Charles de Gaulle airport following the granting of antitrust immunity to the Air France - Delta partnership within the Skyteam alliance $^{3}$. Foreclosing on the outside carriers is a perfectly rational strategy for the alliance members, as it not only increases their revenue (the passenger spends all his/her

\footnotetext{
1 All together now - Why antitrust immunity granted in Washington may not wash in Europe, The Economist, Oct $29^{\text {th }} 2009$.

2 Although we will use the term 'antitrust immunity' (which refers to US antitrust laws) throughout the paper, our analysis also applies to the European context.

${ }^{3}$ Report of James D. Reitzes, Dorothy Robyn \& Kevin Neels (The Brattle Group), Docket No. OST-200419214, (June 24, 2005).
} 
money 'within' the alliance), but also lowers their cost via economies of traffic density (and increases the rivals' cost for the same reason) ${ }^{4}$. Foreclosure strategies can be implemented either by a direct refusal to deal, or by setting prohibitively high fees for accepting such passengers. Whatever the exact mechanism, the end result will be higher traffic by the partner airlines with antitrust immunity and lower traffic by the outside airlines on routes to/from the partner airlines' hub airports. This is the contention tested in this study. ${ }^{5}$

We find clear support for our hypothesis in the data. Our estimation results indicate that outside airlines carry up to eight percent fewer passengers to immunized alliance members' hubs as compared to other routes within their networks. At the same time, antitrust immunity increases traffic on routes operated by the respective member airlines out of their hubs by over four percent (as compared to the otherwise equal outside airlines' services), and leads to a dramatic (up to 25 percent) increase in total passenger volume on the routes between the alliance members' hub airports. The same effects, however less robust and half the size of those estimated for the passenger volumes, are observed for the frequency of flights. Traffic between the hubs of competing alliances (another category of markets where foreclosure is possible) is generally similar to that of the outside airlines. Net effects (in terms of passenger volumes and frequency of service) of this foreclosure vary for different categories of markets, and are either ambiguous (at worst implying a small reduction in traffic with potentially anti-competitive outcomes), or indicate higher total traffic. A detailed welfare analysis is outside the scope of this study, as comprehensive pricing data for international airline markets are not available. However, we are able to point to cases where foreclosure stipulated by the antitrust immunity may hurt consumers on certain routes.

The remainder of the paper is organized as follows. The next section is a primer on the antitrust economics of market foreclosure, followed by an overview of the role of antitrust immunity for airline alliances. This is complemented by a discussion of the link

\footnotetext{
${ }^{4}$ On the margin, if a connecting passenger comes from within your alliance rather than from the outside, your load factor increases, and that of your rival falls, which (due to economies of traffic density) increases the difference between your per passenger cost and your rival's.

${ }^{5}$ Among others, Reitzes and Moss (2008) identify anti-competitive foreclosure as the result of antitrust immunity to airline alliances as a policy relevant issue.
} 
between foreclosure and airline partnerships. Subsequently, we describe the data, present and discuss the data analysis results, and conclude. Some of the information and tables are in the Appendix.

\section{Market Foreclosure and Antitrust: Fundamentals}

Market foreclosure involves denying actual or potential competitors access to either an essential input or customers, and thereby preventing them from competing. The tools in the foreclosing firm's toolbox include vertical integration with competitors, refusal to deal, exclusive arrangements, and price discrimination. In either case, the visible outcome of such interaction is lower quantity (market share) of the firm being foreclosed on. The general concept of foreclosure can be of relevance in no fewer than four areas of antitrust policy: mergers and acquisitions, monopolization, vertical restraints, and horizontal agreements (Steuer, 2008). With respect to mergers and acquisitions, we can distinguish between input foreclosure and customer foreclosure. Input foreclosure involves the upstream firm restricting access to its input to the downstream rivals. This raises downstream rivals' costs and so reduces competition at the downstream level, leading to higher prices downstream. In the case of customer foreclosure, the downstream firm restricts its purchases from upstream firm's rivals, leading to the loss of economies of scale - and therefore higher prices - for the upstream rivals. This in turn allows the downstream firms to raise their prices. Although both theoretical concepts are based on sound economics (Ordover, Salop \& Saloner (1990, 1992); Riordan (1998)), antitrust investigations need to show the ability to foreclose, the incentive to foreclose, and whether such a foreclosure strategy would have a significant detrimental effect on competition downstream (European Commission, Non-horizontal merger guidelines, para. 32). Generally, foreclosure as such is not necessarily an anti-competitive practice, but may very well be socially beneficial in certain circumstances such as free-riding by the downstream units or excessive entry (Rey and Tirole, 2007).

In fact, empirical studies of market foreclosure generally point to the dominance of the pro-competitive effects of this practice. Mullin and Mullin (1997) argue that US Steel's acquisition of one of its suppliers led to substantial efficiency gains rather than market foreclosure. Slade (1998) shows that divestiture of pubs by breweries - effective 
removal of possibility of foreclosure - yielded higher prices for beer at pubs. More recently, Hortacsu and Syverson (2007) found no evidence of anti-competitive effects of vertical foreclosure in the cement and ready-mixed concrete industries; instead, the authors suggest that vertical integration yields lower prices, higher quantity, and does not create any additional entry barriers. Shenoy (2008), using an event study analysis covering a large sample of mergers, claims that efficiency is the main rationale for mergers. Derdenger (2009) studies foreclosure in the video game console industry, and suggests it is pro-competitive. An opposing side is represented by Hastings' (2004) study of the gasoline market in Southern California. The author showed that the takeover of independent Thrifty stations by ARCO resulted in higher gasoline prices at the nearby stations, indicating lower competition following the vertical integration.

\section{Airline Alliances and Antitrust Immunity}

Airline partnerships are not a recent development in the commercial passenger airline industry. Capacity, cost and revenue sharing arrangements have been commonly wired into the bilateral air service agreements regulating (and severely restricting) competition on the international markets since World War II. Airline partnerships in their modern form started appearing in the early 1990s, with airlines coordinating their handling of interline passengers via agreements of various types. The most common and policy relevant form of such agreements involves codesharing, whereby flights are assigned the partner airlines' flight number(s), and are effectively incorporated into those carriers' networks. Such services are oftentimes jointly marketed by the partner airlines, and are sometimes supplemented with blocked-space arrangements, whereby a certain number of seats on the flight are sold directly by the partner airline. Multi-airline codesharing agreements led to emergence of the global airline alliances, each of which started from a partnership between a US and an EU carrier. Oneworld developed around the partnership between American Airlines and British Airways; Skyteam evolved from the Delta Air Lines - Air France alliance; and the current Star Alliance is the expanded United Airlines - Lufthansa partnership.

Looking for more freedom to coordinate various aspects of their joint operations, the partner airlines sought antitrust immunity, or the right to jointly set fares throughout 
their international networks, as well as to establish revenue-sharing agreements. This aspect of the airline partnerships is actually not understood too well in the literature. A number of theoretical models (e.g. Park, 1997, Brueckner, 2001, Brueckner and Whalen, 2000) model the alliances as effective mergers. Of the empirical studies of international airline partnerships (Oum et al., 1996, Park and Zhang, 2000, Brueckner and Whalen, 2000, Whalen, 2007, Brueckner, 2003) only the latter two attempt to empirically distinguish the effect of the antitrust immunity on airfares.

Between 1992 and 2009, the US DOT investigated 35 applications for antitrust immunity for the international services of various airline alliances. ${ }^{6}$ Only three applications were disapproved ${ }^{7}$ by the US DOT, two are pending (as of February 2009), and two applications were dismissed on request of the airlines before a final decision was announced. All of the remaining 28 applications were approved subject to conditions. Excluding the twelve applications of alliances without any involvement of a European carrier leaves 16 approved transatlantic applications for antitrust immunity. All antitrust immunity granting decisions that fall into the time period covered by our data are described in the Appendix. ${ }^{8}$

Antitrust immunity represents a higher degree of cooperation than codesharing agreements, and changes the airlines' incentives with respect to the acceptance of interline passengers. While codesharing - either with or without antitrust immunity does not technically preclude an airline from accepting interline passengers from the nonpartner airlines, immunity makes market foreclosure more likely. An airline accepting an interline passenger on its flight both increases its revenue and lowers per passenger cost via economies of traffic density. Antitrust immunity, when supplemented with a revenue

\footnotetext{
${ }^{6}$ The only domestic airline alliance investigated by the DOT was between Aloha Airlines and Hawaiian Airlines in 2002.

${ }^{7}$ American Airlines - British Airways (1999), American Airlines - British Airways (2002), Delta Air Lines - Northwest Airlines - Air France - Alitalia - CSA Czech Airlines - KLM (2006)

${ }^{8}$ Between 1994 and 2008, the European Commission investigated 21 cases of proposed airline alliances. However, 10 out of the 21 cases had a solely European focus and are therefore of no particular interest here. Of the remaining 11 transatlantic alliance applications, at the beginning of 2010 four applications (including the three remaining global alliances) are still awaiting their final decisions, two applications became dormant due to DOT's dismissal, two became obsolete as the partnership ended before a decision was made, and one application was extended to the current SkyTeam investigation. In sum, there appears to be only one transatlantic alliance that was approved subject to conditions (Lufthansa-SAS-United in 2002).
} 
sharing agreement, is equivalent to joint profit maximization ${ }^{9}$, and therefore strongly discourages accepting interline passengers from outside airlines. Even in case of antitrust immunity without explicit network-wide revenue sharing ${ }^{10}$, partner airlines can share the revenue from the interline fares in such a way as to foreclose the market for outside carriers. Antitrust immunity allows the partner airlines to effectively set "transfer prices" for the interline itineraries within the alliance. As an example, suppose airline A can feed its traffic to either carrier B or C. Suppose the total fares for the A-B and A-C interline trips are the same. Then, if airlines A and B have antitrust immunity, they can split the interline fares in such a way that airline A obtains a disproportionately large share of the total interline fare for feeding its passengers to its partner carrier B. This arrangement can be reciprocal, so that airline $\mathrm{B}$ will recoup the losses by receiving the disproportionately large share of the total fare for feeding traffic to airline A. This kind of "transfer prices" can eliminate the non-alliance airline $\mathrm{C}$ as a competitor.

Note that with a simple codesharing the above described agreement is not feasible, as explicit coordination of prices for the interline trips is not allowed. Besides, it should be noted that the non-acceptance of the interline passengers from carriers outside of the immunized alliance increases the respective airlines' cost due to lower load factors, again working through economies of traffic density.

\section{Antitrust Immunity and Foreclosure}

The possibility of foreclosure in airline partnerships has been suggested by Chen and Gayle (2007), and Bilotkach (2007). Both papers model alliances with antitrust immunity and profit sharing. In either model, where an airline can choose from a variety of potential alliance partners, the airline not chosen as a partner is unable to carry its passengers beyond its network. This issue is illustrated in Figure 1, depicting the network structure borrowed from Bilotkach (2007). Over this network, Airline 1 effectively forecloses the A-to-C market to Airline 3 upon setting up the alliance with Airline 2.

\footnotetext{
${ }^{9}$ For more details on revenue sharing agreements within airline alliances, see Brueckner and Proost (2009). ${ }^{10}$ With revenue sharing, partner airlines may split revenue not only from the interline, but also from the online (i.e., single-airline) passengers.
} 
From the practical point of view, vertical foreclosure need not involve outright refusal to accept the interline passengers from anyone except the alliance partner. What changes once the two airlines start cooperating is the ability to remove double marginalization for their interline services. Antitrust immunity is a sufficient (but potentially not a necessary) condition for such a removal of double marginalization. Most studies of airline consolidation do not formally distinguish between alliances with and without antitrust immunity; and some papers (e.g., Bilotkach, 2005; Bilotkach and Hüschelrath, 2010) suggest the possibility for the alliance without antitrust immunity to yield the removal of double marginalization. Yet, as we discussed above, antitrust immunity allows explicit price coordination, and gives the partner airlines a possibility to either set up a joint venture with revenue sharing or split the total interline fares to restrict interlining outside of their network whenever possible. In addition, Reitzes and Moss (2008) note that foreclosure will be more successful the higher the gateway's reliance on connecting traffic and the fewer the options for channeling passengers via alternative hub airports. They further suggest that the current structure of the transatlantic airline industry appears more conducive to foreclosure at EU rather than US gateways, due to the relative dominance of EU countries' flag carriers on the respective domestic markets.

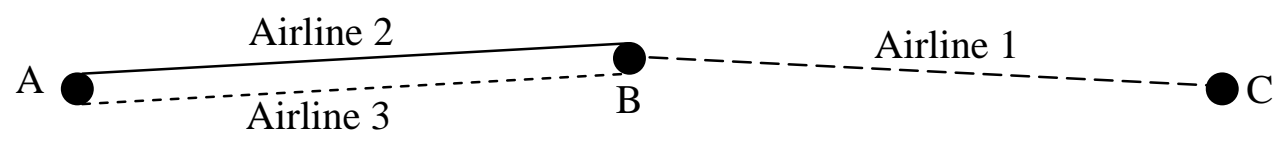

Figure 1: Network with choice of alliance partner

The above-stated immediately suggests a simple hypothesis for detecting foreclosure following an airline partnership. Namely, foreclosure will entail non-alliance carriers lowering their traffic from/into an alliance hub; while alliance members would increase this traffic. This point is illustrated in Figure 2, which breaks down non-stop transatlantic traffic at Frankfurt airport (FRA) by operating carriers' affiliation with the Star Alliance partnerships that enjoy antitrust immunity. We can clearly see that Star Alliance traffic 
has been increasing over the years, while transatlantic traffic by the airlines outside of Star Alliance has been declining or constant ${ }^{11}$.

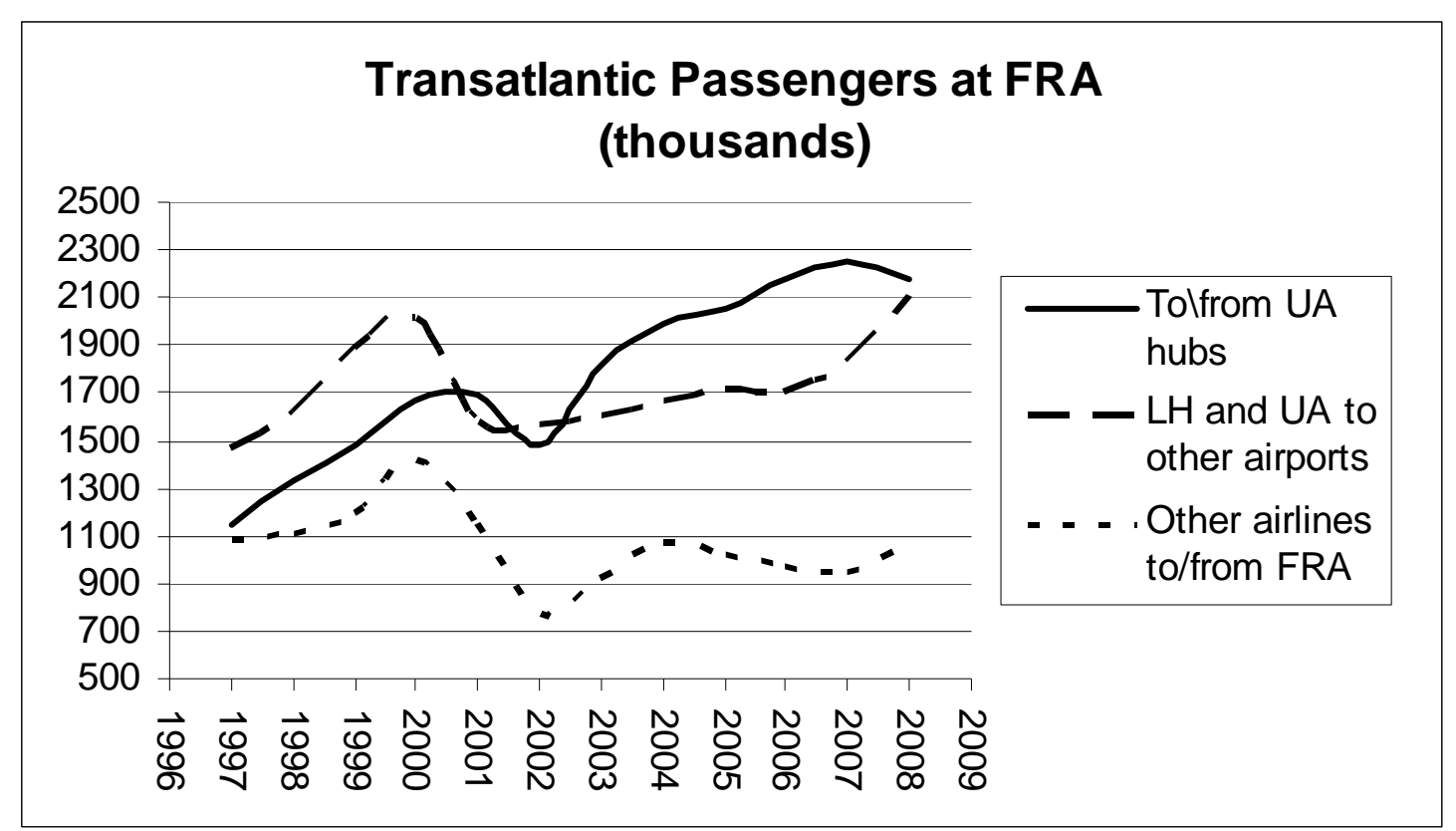

Note: Computed from T-100 dataset (see data section of the paper). LH = Lufthansa; UA = United; the two airlines have antitrust immunity since 1996. Services between to UA hubs include non-stop flights to Washington Dulles, Chicago O’Hare, Denver, and San Francisco by United or Lufthansa.

Figure 2: Non-stop transatlantic passenger traffic at Frankfurt airport

Let us now examine which markets can be affected by foreclosure at hub airports of the immunized alliance members. Figure 3 depicts a simple network with two competing airline alliances. Airports S1, H1, and $\mathrm{H} 2$ are located across the Atlantic Ocean from H3, H4, and S2. Let us call the partnership between the airlines operating hubs H1 and H3 Alliance 1; while Alliance 2 members will operate hubs $\mathrm{H} 2$ and $\mathrm{H} 4$. Then we can define the following types of international markets:

- Markets between the hubs within an Alliance: H1-H3 and H2-H4 routes;

- Markets between the hubs of competing Alliances: H1-H4 and H2-H3;

- Spoke-overseas hub routes: S1-H3, S1-H4, S2-H1, and S2-H2; note that in addition to one-stop flight possibilities, we may also have non-stop flights on these markets (not singled out here to keep Figure 3 as simple as possible).

\footnotetext{
${ }^{11}$ Note that while Star Alliance membership has grown over the years, Star Alliance transatlantic services with antitrust immunity to/from Frankfurt airport have been performed by either Lufthansa or United. US Airways, while a member of Star Alliance, has not had antitrust immunity, and therefore its services are included into the "other airlines” category in Figure 2.
} 
- Spoke-spoke routes: S1-S2.

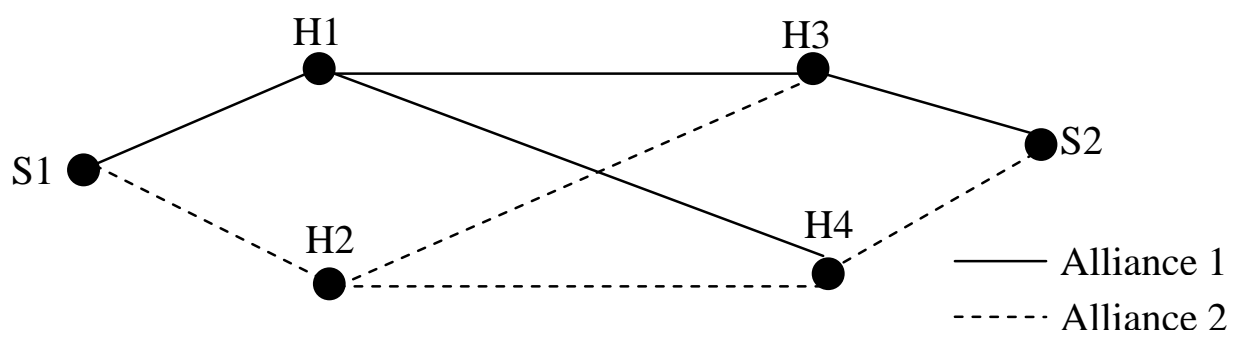

Figure 3: Simple Network with Two Alliances

Market foreclosure will yield a reduction of traffic on H1-H4 and H2-H3 routes. Spokeoverseas hubs routes may also be affected. Consider the S1-H3 market. In the extreme case, Alliance 2 may end up closing down the H2-H3 segment of its network (as it is unable to operate this market profitably without passengers connecting to spokes via H3). Even if the segment is not closed down (so that alliance members only reduce frequency of service), the position of Alliance 2 on the S1-H3 route looks less favorable when compared to Alliance 1. At the same time, the reduction in competition on these routes can be offset by the lower cost; therefore, the net effect on prices is generally uncertain.

Spoke-to-spoke markets (S1-S2) are not affected much by foreclosure, as competition between the airlines is simply replaced by the competition between alliances. It is however true that the S1-S2 passengers will now have fewer options, as routings S1H1-H4-S2 and S1-H2-H3-S2 are no longer available to them.

In addition to the markets depicted in Figure 3, foreclosure may affect non-stop transatlantic traffic from the alliance hubs to gateway points other than hubs across the ocean. Such routes are important to the extent that they are served by the airlines which are not members of either of the two alliances - those carriers may be foreclosed on, leading to lower competition.

The net effect of competition between the alliances is increased specialization of individual alliance members on channeling the passenger traffic via the alliance partners' hubs, and reduction in traffic to the competing alliance's hub airports. While over the entire network the effect of this network reorganization could be to increase the number of markets served, and competition between the alliances may intensify (especially on the 
spoke-to-spoke markets); we have identified some markets where competition will be decreased. Specifically, those markets include all routes originating and terminating at the hub airport of an immunized alliance member. Our conclusion is actually quite different from the approach regulators have up to now applied to antitrust immunity, where only routes between alliance members' hubs have been considered susceptible to reduced competition with antitrust immunity. Last but not least, not all airlines are alliance members and the formation of airline alliances puts those carriers into a clearly disadvantageous position, also decreasing competition on the affected markets. As an example, if we suppose that the H3-S2 route is also served by a non-alliance carrier, the formation of the alliance will decrease competition in this market.

In the end, we can formulate the following testable hypotheses. First, we expect the airlines without antitrust immunity protection to serve fewer flights and carry fewer passengers (as compared to what they offer elsewhere on their network) on markets involving hub airports of members of alliances that enjoy antitrust immunity. Second, antitrust immunity is expected to yield lower traffic between the hub airports of members of competing alliances.

\section{Data}

\subsection{Sample and Key Variables}

Our main data source is the T-100 dataset for international airline services provided by the US Department of Transportation. This dataset includes monthly information on all non-stop services between the USA and the rest of the world. Each entry contains information about the segment's endpoints, operating carrier, and monthly totals for the number of departures performed, seats offered, and passengers carried on this particular segment. From this dataset we have selected data for travel between the USA and all current EU members, plus Switzerland and Norway, for the years 1992 to 2008 . We have retained only passenger services, yet eliminated services with fewer than ten monthly departures. $^{12}$ Overall, we ended up with 51,896 observations, spanning 377 non-

\footnotetext{
${ }^{12}$ Since we defined markets as not directional, ten departures actually correspond to five flights each way, or about one scheduled flight per week.
} 
directional $^{13}$ airport-pair markets and 796 airline-market combinations between 38 US and 57 European airports.

Our key independent variables will be types of airline services, defined according to both the airline's membership in an alliance enjoying the antitrust immunity, and the endpoints' status as a hub in one or the other airline's network. Specifically, we differentiate between:

- Immunized alliance members’ services between their respective hub airports (e.g., KLM flight from Amsterdam to Detroit); we will call those "Services between immunized hubs"

- Immunized alliance members' services from their hub airports to a hub airport of a competing alliance with antitrust immunity (e.g., KLM service from Amsterdam to Chicago O’Hare after Star Alliance obtained antitrust immunity); to be denoted "Services between competitors' hubs"

- Immunized alliance members' services from their hub airports to airports which do not serve as hubs for any immunized alliance member (e.g., KLM service from Amsterdam to Boston); we will refer to those as "Other immunized alliance services" - Services to immunized alliance members' hub airports by airlines which are themselves not immunized alliance members (e.g., British Airways services to such airports such as Chicago O’Hare, Denver, Washington Dulles, etc.). This category will be called "Other services to alliance hubs".

These four categories combined encompass (in 2008) up to 70 percent of all non-stop services in the dataset, as evident from Figure 4. That figure starts from 1996 rather than 1992, as 1996 is the first full year when we observe several competing alliances with antitrust immunity (KLM-Northwest partnership; Delta-Swissair-Sabena-Austrian Airlines partnership; as well as Lufthansa-United and Lufthansa-SAS immunity within Star Alliance). It can be observed that between 1996 and 2002 there has been a steady growth in the share of services involving hubs of alliance partnerships with antitrust immunity; since then this share has stabilized at about 70 percent. This implies that seven out of ten flights on the transatlantic markets (US-EU plus Norway and

\footnotetext{
${ }^{13}$ This means that JFK-Heathrow traffic is lumped together with Heathrow-JFK passengers.
} 
Switzerland) involve either one or two airports used as hubs by the airlines participating in partnerships with antitrust immunity.

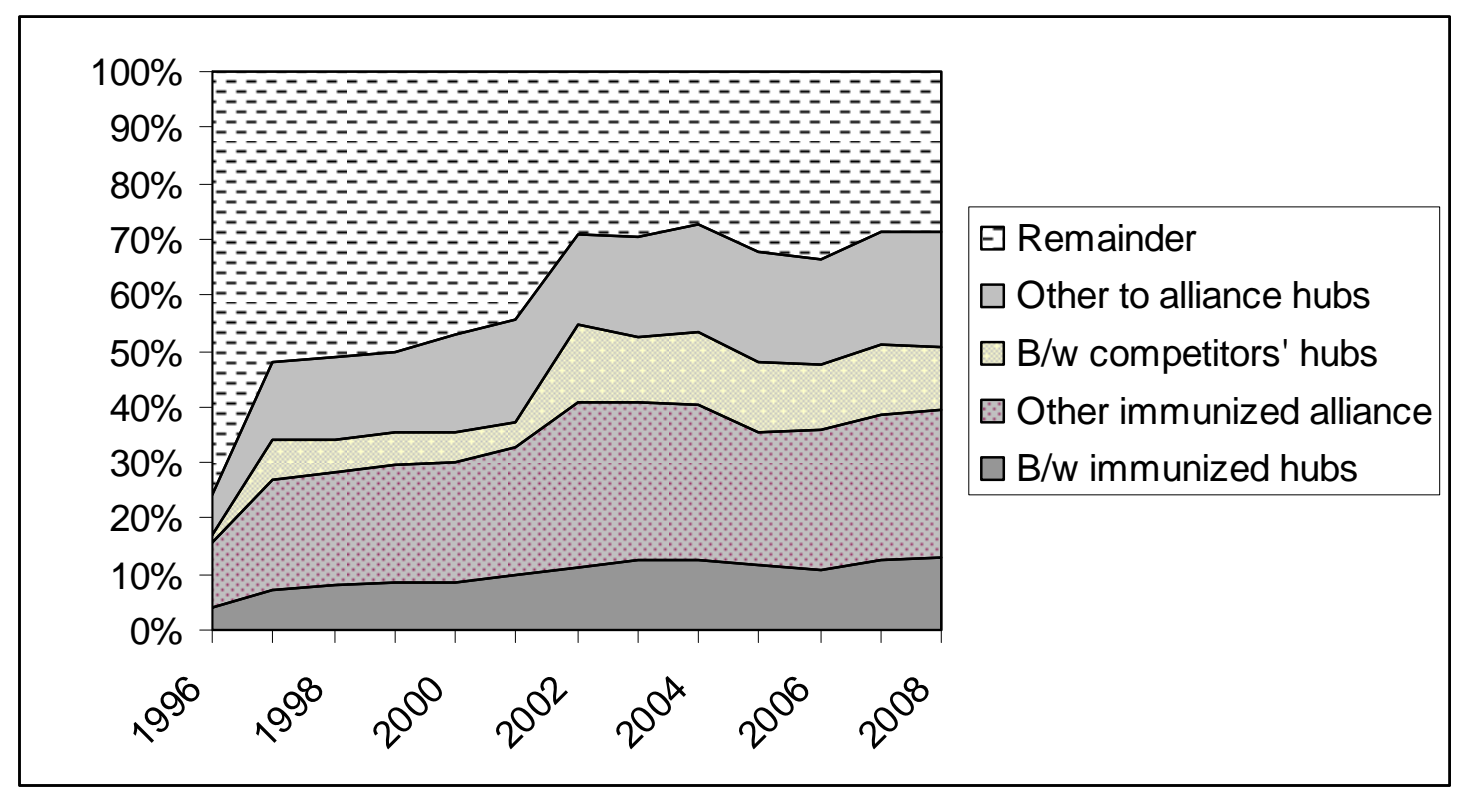

Note: Market shares are based on frequency of service; shares based on number of passengers carried and seats offered are similar.

Figure 4: Market Share of Services Involving Hubs of Alliances with Immunity

To correctly classify the services in line with the above categories, we need information on both the airlines' hub airports and the timeline of antitrust immunity decisions. In addition, we know that some of the airline partnerships which had been granted antitrust immunity were eventually dissolved; therefore it was necessary to determine the corresponding timeline as well. US DOT's decisions on granting of antitrust immunity are publicly available; we used them to construct the timeline presented in the Appendix. Internet research revealed the dates of dissolution of partnerships. For the purpose of data analysis, we considered immunized alliances as operational starting from the month following the granting of antitrust immunity until either the month in which the partnership was dissolved or (for currently active alliances) the end of 2008.

Hub airports have been designated based on the structure of the airlines' networks. EU airlines' hubs mostly corresponded to the respective countries' capitals (except for Lufthansa, which operates hubs at both Frankfurt and Munich airports; Alitalia, using both Rome Fuimicino and Milan Malpensa as hubs; and SAS, operating 
hubs at Copenhagen, Stockholm, and Oslo). For the US airlines participating in airline partnerships with antitrust immunity, we have designated the following airports as hubs:

- American Airlines: Chicago O’Hare, Dallas Ft. Worth, Miami

- United Airlines: Chicago O’Hare, Denver, San Francisco, Washington D.C. (Dulles airport)

- Northwest Airlines: Detroit, Minneapolis, Memphis

- Delta Air Lines: Atlanta, Cincinnati, Salt Lake City, ${ }^{14}$ New York JFK

\subsection{Control Variables}

In the data analysis that follows, we will use the following control variables. At the country level, we include data on the volume of trade between the USA and each of the European countries, as well as the information on whether there is a Visa Waiver Program ${ }^{15}$ in effect for a given European country, and whether there is an Open Skies Agreement ${ }^{16}$ in place. All three - higher trade volume, Visa Waiver Program and Open Skies Agreement - are expected to yield higher travel volumes between the US and a foreign country. However, the effect of each of these variables at the individual route level is uncertain, as airlines may open up new routes to a country in response to each of these factors; and the travel volume on some 'older' routes may decline (e.g., if an airline starts serving Stuttgart in addition to Frankfurt, some passengers which used to fly to Frankfurt will now go to Stuttgart, so the passenger volume on flights to Frankfurt may decrease).

The market-level control variables include geometric averages of endpoints' per capita income and population; as well as the airport-pair market level Herfindahl index (we will use the index based on passenger volumes).

\footnotetext{
${ }^{14}$ There have been no transatlantic services out of Salt Lake City until 2008.

${ }^{15}$ The Visa Waiver Program was introduced in 1986 and allows citizens of certain countries to visit the USA for tourism or business purposes for up to 90 days without avisa. Of the current EU members, only Poland, Greece, Bulgaria, Romania, and Cyprus are not participating in this program.

${ }^{16}$ Prior to the provisional opening of the Open Aviation Area to include US and EU (covering Switzerland and Norway as well), the US signed Open Skies Agreements with individual countries. An Open Skies Agreement removes all barriers to entry with non-stop services between the US and a foreign country, except for the "nationality clause" (i.e., airlines operating such services had to be owned and effectively controlled by nationals of either of the two countries).
} 
Airline indicator variables will be used where appropriate to control for the airline-specific effects. Time-specific heterogeneity will be controlled for by year and month indicator variables. The following Table includes descriptive statistics on our variables.

Table 1: Descriptive Statistics of Variables

\begin{tabular}{|c|c|c|c|c|}
\hline & Mean & Std. Dev. & Minimum & Maximum \\
\hline Monthly frequency & 66.59 & 44.02 & 11.00 & 494.00 \\
\hline Monthly passengers & $13,304.17$ & $10,121.67$ & 101.00 & $107,457.00$ \\
\hline Monthly seats & $17,713.43$ & $12,828.48$ & 392.00 & $145,576.00$ \\
\hline Between immunized hubs & 0.07 & 0.26 & 0.00 & 1.00 \\
\hline Other immunized alliance & 0.18 & 0.38 & 0.00 & 1.00 \\
\hline Between competitors' hubs & 0.08 & 0.27 & 0.00 & 1.00 \\
\hline Other to alliance hubs & 0.17 & 0.37 & 0.00 & 1.00 \\
\hline HHI & 0.71 & 0.28 & 0.18 & 1.00 \\
\hline Visa Waiver Program & 0.96 & 0.20 & 0.00 & 1.00 \\
\hline Trade volume (million US\$) & $53,539.63$ & $35,645.67$ & 399.60 & $152,001.00$ \\
\hline Open Skies Agreement & 0.46 & 0.50 & 0.00 & 1.00 \\
\hline
\end{tabular}

\section{Data Analysis and Results}

\subsection{Methodology}

Our main hypothesis is that members of airline partnerships with antitrust immunity will have an incentive to block feeder traffic from the airlines that are not part of their alliance. This can be operationalized via direct refusal, increased interlining fees for accepting passengers of outside airlines, and/or attracting passengers from within the alliance due to price coordination authorized by the antitrust immunity. In either case, we deal with foreclosure of markets beyond the alliance members' hub airports to competitors.

In our data, foreclosure will show itself via lower frequency of service and passenger volumes, offered by the outside carriers to hub airports of members of the alliance with antitrust immunity. Besides, routes between the competing alliance members' hubs might be affected as well. We will be able to directly test these hypotheses using our route classification outlined in the previous section. Note that the baseline category in our sample consists of services performed by the airlines which are not members of the partnerships with antitrust immunity on routes that do not involve any of the alliance members' hubs. Thus, a negative coefficient on the indicator for services offered by the outside carriers to hub airports of members of the alliance with antitrust 
immunity will mean that these airlines offer fewer flights to hubs of alliance members as compared to the identical routes elsewhere in their networks.

Our dataset is an unbalanced panel. We thus can estimate the airport-pair market level and airline-airport pair level fixed effects. The latter should give a better picture, as it will enable us to take better account of the fact that most carriers in our sample operate hub-and-spoke networks, so that frequency decisions are made taking into account demand not only on spoke-to-hub markets, but also on spoke-to-spoke routes. In the airline-market fixed effect model, the effects we are interested in will be identified by the variation in the relevant variable within a given airline-market cross-section. As an example, consider Delta Air Lines' service from Atlanta to Vienna. This service will be classified in the outside category before antitrust immunity was granted to the Delta Austrian partnership (from January 1992 till June 1996); as well as after the partnership ended and before the Austrian - United pair obtained antitrust immunity within Star Alliance (April 2000 toJanuary 2001). After Delta - Austrian obtained antitrust immunity and before their partnership ended (July 1996 to March 2000), this service will be classified as service between immunized hubs. In the period from February 2001 until January 2002, Austrian was a member of a partnership with antitrust immunity, while Delta was not: this implies that Delta service from Atlanta to Vienna will be in the other service to alliance hubs category during this period. In January 2002 Delta Air Lines itself became a part of an alliance with antitrust immunity. From February 2002 until the end of 2008 (this is how far our dataset spans) Delta's Atlanta - Vienna service will be in the service between competitors' hubs category. Overall, about one third of all airlinemarket combinations in our sample move between the above-described categories at least once (the share is higher if we restrict our sample to services of 'legacy' carriers - see below for a relevant description).

Additionally, to take advantage of the dynamic panel data structure, we have estimated the system generalized method of moments (system GMM) estimator proposed by Arellano and Bover (1995). The Arellano - Bover estimator builds upon the Arellano and Bond (1991) GMM estimator that treats the model as a system of equations - one for each time period - where the predetermined and endogenous variables in first differences are instrumented with suitable lags of their own levels. The innovative idea in Arellano - 
Bover was to add the original equations in levels to this system. The model we report includes two lags of the respective dependent variable on the right-hand side, and third to sixth lags are used as instruments.

In addition to running regressions on the entire sample; we will perform a series of robustness checks for our results. First, we will restrict our sample to services performed by the 'legacy' carriers; these include EU countries' traditional flag carriers and major US airlines. In this way, we eliminate services by smaller and charter carriers as well as by the airlines from other parts of the world (mostly Asian carriers) performing transatlantic services under the fifth freedom rights ${ }^{17}$. This restriction decreased the number of observations by about twelve percent. Second, we exclude services to/from the United Kingdom - by far the largest transatlantic market (at the country level). This country's flag carrier (British Airways) has faced a number of obstacles in trying to obtain antitrust immunity for its partnership with American Airlines, and travel between the US and the UK has been subject to some idiosyncratic rules, most notably entry restrictions at London Heathrow airport ${ }^{18}$. Third, to make sure the airlines' potentially non-random entry and exit decisions do not bias our results, we restricted our sample to services observed in at least 190 out of 204 possible months. This restriction constrained us to working with 93 airline-market combinations.

\subsection{Results}

Results of our data analysis exercise are presented in Tables 2 through 5 . Table 2 includes results of the airport-pair-market fixed effects model; Tables 3 and 4 report airline-market fixed effects model results. Tables 3 is essentially Table 2 with airlinemarket fixed effects; Table 4 reports results for the sub-sample including 'steady' services (i.e., those observed in at least 190 out of 204 possible months). Table 5 reports the Arellano - Bover dynamic panel GMM estimation results.

The estimation results are consistent with the market foreclosure hypothesis, and are robust to excluding non-legacy carrier services, services to/from the United Kingdom,

\footnotetext{
${ }^{17}$ Fifth freedom rights allow the airline to carry revenue passengers between foreign countries as part of the service to/from its own country (e.g., under the fifth freedom right Air India is allowed to carry LondonNew York passengers on the respective segment of its New Delhi-London-New York service).

${ }^{18}$ Up to May 2008, two US (American and United) and two UK (British Airways and Virgin Atlantic) airlines were allowed to perform direct transatlantic services out of this airport.
} 
and 'sporadic' services. Specifically, fixed effects results suggest antitrust immunity leads to a 2.5 to 6 percent decrease in the frequency of service by the outside carriers serving the newly immunized hub (based on the airline-market fixed effects specifications). The effect on the passenger volumes is even greater (a 4.8 to 8.5 percent drop, and generally 1.5 to 2 times the effect on frequency), suggesting excluded airlines switch to a smaller aircraft and/or end up with lower load factors on their services to the newly immunized hubs. GMM estimation results indicate an effect of a smaller magnitude (0.7 to 1.5 percent for frequency, and 2.6 to 3.5 percent for passenger volume), while the ratio between the frequency and passenger volume effects is the same as for the fixed effects models.

Evidence of foreclosure on routes between the hub airports of competing partnerships with antitrust immunity is less robust. From Table 3 we observe that members of partnerships with antitrust immunity change the frequency of their services to the competing partnerships' hubs in line with how they make the same choices elsewhere on their networks (except for markets between the alliance members' hubs, where the frequency of service increases dramatically following granting of antitrust immunity). However, emergence of an alliance with antitrust immunity leads to a 3-5 percent decrease in passenger volume to the newly immunized hub by the member of the competing immunized partnership. The results in Table 4 are more consistent with market foreclosure on the markets between the competitors' hub airports. In general, if we compare results for the airlines included into and excluded from the airline partnerships with antitrust immunity, we see that the magnitudes of foreclosure effects are similar for the two groups of carriers, but the general level of both frequency and passenger volumes tends to be higher for the airlines included in an immunized partnership. GMM estimation results indicate an interesting relationship: once the competing alliance is granted antitrust immunity, its direct rivals increase both frequencies of service and passenger volumes on flights to the respective hub airports. However, effect on passenger volumes is smaller than on flight frequency. Further, notice that members of partnerships with antitrust immunity increase passenger volumes on other routes out of their hubs to a larger extent than on routes to the competing 
alliance members' hubs (despite similar effects on frequency of service). This evidence can be viewed as consistent with market foreclosure, albeit to a small degree.

The results reported in Table 6 clearly indicate that the foreclosure effects manifest itself in the airlines' load factors rather than the carriers' choice of aircraft size, with the exception of routes between the competitors' hubs. This is understandable, as the carriers effectively face a lower bound on the size of aircraft which can be used for transatlantic services - one cannot fly those routes using aircrafts smaller than Boeing757 or 767 , seating about $200-250$ passengers.

Some of the control variables exhibit surprising behavior. Most strikingly, the relationship between market concentration and frequency/passenger volumes is positive. This contradicts the findings of other recent research (e.g., Pai, 2010; Bilotkach, 2010; Bilotkach et al., 2010). However, those other studies use different datasets, and examine airlines' frequency choices in the unregulated airline industry; in our case, entry restrictions are present, at least in the form of the nationality clauses, and these constraints could be driving the frequency-concentration relationship we discovered. Negative effects of population and trade volume in some specifications are most probably driven by the airlines' hub-and-spoke networks. Open skies agreements sometimes imply a negligible or even a negative effect on frequency; but the effect of market liberalization on the passenger volumes is clearly positive.

\subsection{Discussion}

Our data analysis showed that airlines excluded from the partnerships with antitrust immunity end up decreasing their frequency of service, and experience lower passenger traffic volumes (mostly due to a lower load factor rather than the use of smaller aircraft) for their services to the immunized alliance members' hub airports. This is consistent with the market foreclosure hypothesis we postulated. This subsection addresses the question of whether the foreclosure which we detected is pro- or anti-competitive.

Before we proceed, several points need to be stressed. First, we do not study the price effects of antitrust immunity. This mainly has to do with the fact that complete and reliable price data for this market is not available - publicly available datasets only include information on pricing by the US carriers and partnerships including US 
airlines $^{19}$ ). Thus, all claims we are making in this subsection will be based on results for passenger traffic volumes, and can sometimes be interpreted differently depending on what one believes about the nature of competition in the commercial passenger airline industry. Second, the transatlantic airline market had for some time exhibited competition between several airline partnerships with antitrust immunity - this will also influence the interpretation of our findings. Third, in our discussion of foreclosure effects we will ignore any possible effects of services having more stops than the ones under consideration.

Recall from our earlier discussion that several types of international markets can be defined relative to the structure of partner airline's networks. Specifically, we will evaluate the implications of our results for the following categories of markets:

- Markets for travel between the immunized alliance members' hubs (e.g, Amsterdam - Minneapolis);

- Markets for travel between the competing alliance members’ hub airports (e.g., Amsterdam - Chicago);

- Markets for travel from an immunized alliance member's hub airport to non-hub airports (e.g., Frankfurt - Boston);

- Beyond-the-gateway to alliance member's hub airport market (e.g., Tucson to Amsterdam);

- Beyond-the-gateway to beyond-the-gateway markets (e.g., Tucson to Turin).

Let us consider these market categories one by one.

\section{Routes between alliance members' hub airports}

Previous literature identified these markets as the most likely candidates for abuse of market power by partner airlines as the existence of a partnership (especially the one backed by antitrust immunity) leads to reduced competition on those routes. There is however little support for this claim in the empirical literature. We observe that antitrust immunity leads to higher frequency of service and higher passenger volumes on those markets. Of course, most of the additional passengers on Amsterdam-Minneapolis flights

\footnotetext{
19 Thus, available data are most suitable for studying price effects of airline partnerships on the beyond-thegateway routes (e.g., Brueckner, 2003)
} 
do not travel from Amsterdam to Minneapolis, but use this flight as a segment in their journey. At the same time, Minneapolis - Amsterdam customers benefit from the increased frequency of service and the consequent decrease in the total price of travel; not to mention that antitrust immunity can be responsible for the very existence of non-stop services between the partners' hub airports ${ }^{20}$.

\section{Routes between competitors' hub airports}

On these routes we suspected foreclosure to lead to a decline in the frequency and/or passenger volumes. We did not find robust support for our contention in the data. However, the results of the data analysis for the sub-samples of 'steady' services do point to a 5-6 percent decline in passenger volumes on such routes. That is, members of competing alliances with antitrust immunity may foreclose each other on these routes. Therefore, there is some (although not conclusive) evidence of potential anti-competitive effects of market foreclosure on those markets.

\section{Routes from immunized alliance members to non-hub airports}

Our data analysis suggests that we observe strengthening market power on these routes by the airlines included in partnerships with antitrust immunity, as their passenger volume increases, and that of the excluded carriers declines. On duopoly markets falling in this category (we rarely see competition by more than two airlines on these routes), our regression coefficients suggest a zero to slightly negative net effects for antitrust immunity on passenger volumes. The airline with a membership in an alliance with antitrust immunity obtains an advantage over its excluded competitor. The net effect of this development on prices will crucially depend on the nature of competition between the carriers. Overall, we can conclude that foreclosure may yield anti-competitive outcomes on these markets.

\footnotetext{
${ }^{20}$ As an example, Austrian operated non-stop flights to Atlanta only while it had antitrust immunity for its partnership with Delta.
} 


\section{Beyond-the-gateway to alliance member's hub airport routes}

Passengers on those routes are required to make one transfer before (or after) crossing the ocean. Antitrust immunity leads to a clearly dominant position of the partnership whose member operates hub airports across the ocean. For instance, Skyteam alliance will obtain a dominant position on the Tucson to Amsterdam market. This is yet another category of markets where our data analysis results suggest a potential for anticompetitive effects of antitrust immunity via market foreclosure.

\section{Beyond-the-gateway to beyond-the-gateway routes}

Passengers on these routes are probably the biggest winners from antitrust immunity, as actually suggested by Kasper and Lee (2009). When traveling within an alliance, passengers on those markets invariably use the route between the alliance members' hubs as a segment in their journey. A higher frequency of service on the route between the hubs means, other things equal, that antitrust immunity will allow partner airlines to connect more beyond-the-gateway endpoints on both sides of the ocean with their services. The existence of several such airline partnerships ensures at least some degree of competition for passengers on those routes.

Overall, our results suggest that bringing the possibility of market foreclosure as a result of antitrust immunity into consideration allows us to point to the possibility of anticompetitive effects on markets which have generally been considered immune to lower competition as a result of increased airline cooperation. For instance, it has been believed that airline alliances should not affect competition on routes from alliance members' hub airports to non-hub gateways. We show that this might not be true, and suggest that competition on all markets involving hub airport of a member of an alliance with antitrust immunity can decrease through market foreclosure.

To conclude this section, let us evaluate implications of our results for the recently granted antitrust immunity to the Continental Airlines' partnership with European members of Star Alliance. ${ }^{21}$ Simply put, the only routes where we can expect a

\footnotetext{
${ }^{21}$ Up to October 2009, Continental Airlines was not a member of any global airline alliance; however, it did have codesharing agreements with Delta, Northwest, and Virgin Atlantic, among others. In July 2009 the Continental partnership with EU Star Alliance members was granted antitrust immunity, and in October 2009 the carrier officially became a member of Star Alliance.
} 
reduction in non-stop passenger traffic and number of flights are the markets between Continental Airlines' hubs (Houston, Newark, Cleveland) and hub airports of the Skyteam members (most notably Amsterdam and Paris). We will also see more Continental Airlines' airplanes in Frankfurt (the carrier announced its move to the Lufthansa terminal shortly after joining Star Alliance). Any effect on beyond-thegateway to Star Alliance hubs' markets will likely be marginal. On these routes, some travelers will obtain another possible routing within Star Alliance (so that alliance will effectively compete against itself), which should yield benefits to customers. On some routes (most notably from points in Texas), where travel to European Star Alliance members' hubs was offered via either Houston or Dallas on previously non-allied Continental or American Airlines, Continental's position will become stronger, and competition may decrease (in the worst case scenario, American may stop serving cities like Frankfurt or Zurich out of Dallas).

\section{Conclusion}

The theoretical literature has suggested that members of international airline partnership might have an incentive to foreclose the beyond-the-gateway markets to the airlines excluded from the respective alliance. It has also been suggested that such foreclosure will likely be most effective when alliance partners have the right to jointly set fares for the interline services, and engage in revenue sharing arrangements - a privilege otherwise known as antitrust immunity. This paper analyzes and quantifies effects of such market foreclosure.

We conduct an extensive analysis of the data on non-stop services on the transatlantic scheduled commercial passenger airline market. Merging the data with the information on the structure of the airlines' networks and dynamics of the airline partnerships on the same market over the time period from 1992 to 2008, we are able to analyze whether the airlines enjoying antitrust immunity take steps to exclude interline passengers arriving on the rival carriers' flights. We find that antitrust immunity leads to a 2.5-6 percent (0.7-1.5 percent in dynamic panel data GMM estimation) decrease in frequency of service by the non-alliance carriers serving a newly immunized hub. The effect on the passenger volumes is even greater (4.8 to 8.5 percent drop in fixed effects, 
2.6 to 3.5 percent in GMM; and generally 1.5 to 2 times the effect on frequency). This suggests excluded airlines switch to smaller aircrafts and/or end up with lower load factors on their services to the newly immunized hubs. We also find evidence (less robust, however) that antitrust immunity may lead to lower passenger volumes on routes between the competing alliances' hubs.

Based on our results, we suggest that antitrust immunity may lead to reduced competition on all markets (whether non-stop or one-stop) involving alliance members' hub airport(s). In particular, where an immunized alliance member competes with a nonalliance carrier, foreclosure following antitrust immunity results in increased market share inequality and potentially lower total traffic. Note that the literature has up to now only considered markets for travel between alliance members' hub airports as candidates for lower competition following antitrust immunity. We effectively expand the set of markets where antitrust immunity may yield losses to the traveling public.

More generally, our study presents evidence which is somewhat contrary to what is found in the general empirical literature on market foreclosure. Most studies suggest that foreclosure appears to be pro-competitive; we suppose that the competitive effects of market foreclosure might depend on market characteristics. Admittedly, we are unable to analyze the price effects of market foreclosure, and antitrust immunity may bring about cost synergies which will be passed along to travelers in the form of lower airfares, offsetting the negative effects we detect. However, available data does not allow conducting a detailed welfare analysis and lower passenger volumes at the market level are generally not consistent with potentially lower fares.

\section{References:}

Arellano, M., and S. Bond (1991) "Some Tests of Specification for Panel Data: Monte Carlo Evidence and an Application to Employment Equations" Review of Economic Studies, 58, 277-97

Arellano, M., and O. Bover (1995) "Another Look at the Instrumental-Variable Estimation of Error-Component Models" Journal of Econometrics, 68, 29-52

Bilotkach, V. (2005) "Price Competition between International Airline Alliances" Journal of Transport Economics and Policy, 39, 167-189 
Bilotkach, V. (2007) "Complementary versus Semi-Complementary Airline Partnerships”, Transportation Research Part B, 41, 381-393

Bilotkach, V. (2010) "Multimarket Contact and Intensity of Competition: Evidence from an Airline Merger”, manuscript, University of California, Irvine

Bilotkach, V., X. Fageda, and R. Flores-Fillol (2010) "Scheduled Service versus Personal Transportation: The Role of Distance” Regional Science and Urban Economics, 40, 6072

Bilotkach, V. and K. Hüschelrath (2010) "Whither Antitrust Immunity for International Airline Alliances?” working paper

Brueckner, J. (2001) "The Economics of International Codesharing: An Analysis of Airline Alliances”, International Journal of Industrial Organization, 19, 1475-1498

Brueckner, J. (2003) "International Airfares in the Age of Alliances: The Effects of Codesharing and Antitrust Immunity” Review of Economics and Statistics, 85, 105-118

Brueckner, J. and T. Whalen (2000) "The Price Effects of International Airline Alliances” Journal of Law and Economics, 43, 503-545

Brueckner, J. and S. Proost (2009) "Carve-Outs under Airline Antitrust Immunity" working paper

Chen, Y. and P. Gayle (2007) "Vertical Contracting Between Airlines: an Equilibrium Analysis of Codeshare Alliances” International Journal of Industrial Organization, 25, 1046-1060

Derdenger, T. (2009) “”Vertical” Integration and Foreclosure of Complementary Products”, manuscript, Carnegie Mellon University

Hastings, J. (2004) "Vertical Relationships and Competition in Retail Gasoline Markets: Empirical Evidence from Contract Changes in Southern California” American Economic Review, 94, 317-328

Hortacsu, A. and C. Syverson (2007) "Cementing Relationships: Vertical Integration, Foreclosure, Productivity, and Prices” Journal of Political Economy, 115, 250-301

Kasper, D.M. and D. Lee (2009) "Why Airline Antitrust Immunity Benefits Consumers" GCP: The Antitrust Chronicle, September 2009(1), 1-5

Mullin, J. and W.P. Mullin (1997) "United States Steel's Acquisition of the Great Northern Ore Properties: Vertical Foreclosure or Efficient Contractual Governance?” Journal of Law, Economics, and Organization, 13, 74-100 
Ordover J., S. Salop and G. Saloner (1990) “Equilibrium Market Foreclosure” American Economic Review, 80, 127-142

Ordover J., S. Salop and G. Saloner (1990) “Equilibrium Market Foreclosure: A Reply” American Economic Review, 82, 698-703.

Oum, T., J. Park and A. Zhang (1996) "The Effects of Airline Codesharing Agreements on Firm Conduct and International Air Fares”. Journal of Transport Economics and Policy, 30, 187-202

Pai, V. (2010) "On the Factors that Affect Airline Flight Frequency and Aircraft Size" Journal of Air Transport Management, in press

Park, J.-H. (1997) “The Effect of Airline Alliances on Markets and Economic Welfare”, Transportation Research Part E, 33, 181-195

Park, J.-H. and A. Zhang (2000) “An Empirical Analysis of Global Airline Alliances: Cases in the North Atlantic Markets” Review of Industrial Organization, 16, 367-384

Reitzes, J. and D. Moss (2008) “Airline Alliances and Systems Competition”, Houston Law Review, 45, 294-332

Rey, P. and J. Tirole (2007) “A Primer on Foreclosure” in M. Armstrong and R. Porter (ed.) Handbook of Industrial Organization, Vol. 3, North-Holland, Amsterdam

Riordan, M. (1998) “Anticompetitive Vertical Integration by a Dominant Firm, American Economic Review, 88, 1232-1248.

Shenoy, J. (2008) “An Examination of Efficiency, Foreclosure, and Collusion Rationales for Vertical Takeovers”, manuscript, Georgia State University

Slade, M. (1998) "Beer and the Tie: Did Divestiture of Brewer-Owned Public Houses Lead to Higher Beer Prices?” Economic Journal, 108, 565-602

Steuer, R. (2008) "Foreclosure" in W. Collins (ed.) Issues in Competition Law and Policy, Vol. II, ABA Book Publishing, Chicago, 925-937

Whalen, W.T. (2007), “A Panel Data Analysis of Code Sharing, Antitrust Immunity and Open Skies Treaties in International Aviation Markets”, Review of Industrial Organization, 30, 39-61 
Table 2: Airport-pair market fixed effects

\begin{tabular}{|c|c|c|c|c|c|c|c|c|}
\hline \multirow[b]{2}{*}{ Independent Variable } & \multicolumn{4}{|c|}{ Logarithm of frequency is dependent variable } & \multicolumn{4}{|c|}{ Logarithm of total passengers is dependent variable } \\
\hline & Entire sample & $\begin{array}{c}\text { Legacy } \\
\text { carriers only }\end{array}$ & $\begin{array}{c}\text { Excluding } \\
\text { UK }\end{array}$ & $\begin{array}{c}\text { Exclude UK, } \\
\text { legacy only } \\
\end{array}$ & Entire sample & $\begin{array}{c}\text { Legacy } \\
\text { carriers only } \\
\end{array}$ & $\begin{array}{c}\text { Excluding } \\
\text { UK }\end{array}$ & $\begin{array}{l}\text { Exclude UK, } \\
\text { legacy only }\end{array}$ \\
\hline Constant & $\begin{array}{l}2.055 \\
(0.078) \\
\end{array}$ & $\begin{array}{c}2.734 \\
(0.073) \\
\end{array}$ & $\begin{array}{c}2.619 \\
(0.105) \\
\end{array}$ & $\begin{array}{l}3.438 \\
(0.104) \\
\end{array}$ & $\begin{array}{c}7.179 \\
(0.093) \\
\end{array}$ & $\begin{array}{c}7.666 \\
(0.087) \\
\end{array}$ & $\begin{array}{c}7.750 \\
(0.116) \\
\end{array}$ & $\begin{array}{c}8.082 \\
(0.108) \\
\end{array}$ \\
\hline HHI & $\begin{array}{c}0.273 \\
(0.013)\end{array}$ & $\begin{array}{c}0.253 \\
(0.010)\end{array}$ & $\begin{array}{c}0.312 \\
(0.013)\end{array}$ & $\begin{array}{c}0.264 \\
(0.011)\end{array}$ & $\begin{array}{c}0.352 \\
(0.015)\end{array}$ & $\begin{array}{c}0.382 \\
(0.013)\end{array}$ & $\begin{array}{c}0.396 \\
(0.015)\end{array}$ & $\begin{array}{c}0.387 \\
(0.013)\end{array}$ \\
\hline Average population & $\begin{array}{c}1.18 \mathrm{E}-07 \\
(1.54 \mathrm{E}-08)\end{array}$ & $\begin{array}{c}1.43 \mathrm{E}-07 \\
(1.43 \mathrm{E}-08) \\
\end{array}$ & $\begin{array}{l}-4.08 \mathrm{E}-08 \\
(2.40 \mathrm{E}-08) \\
\end{array}$ & $\begin{array}{l}-8.71 \mathrm{E}-08 \\
(2.43 \mathrm{E}-08) \\
\end{array}$ & $\begin{array}{c}6.33 \mathrm{E}-08 \\
(1.83 \mathrm{E}-08) \\
\end{array}$ & $\begin{array}{l}6.18 \mathrm{E}-08 \\
(1.70 \mathrm{E}-08)\end{array}$ & $\begin{array}{l}-1.43 \mathrm{E}-07 \\
(2.85 \mathrm{E}-08)\end{array}$ & $\begin{array}{l}-9.04 \mathrm{E}-08 \\
(2.75 \mathrm{E}-08)\end{array}$ \\
\hline $\begin{array}{c}\text { Average per capita } \\
\text { income }\end{array}$ & $\begin{array}{c}1.67 \mathrm{E}-05 \\
(1.53 \mathrm{E}-06)\end{array}$ & $\begin{array}{c}9.00 \mathrm{E}-06 \\
(1.52 \mathrm{E}-06)\end{array}$ & $\begin{array}{c}1.28 \mathrm{E}-05 \\
(1.93 \mathrm{E}-06)\end{array}$ & $\begin{array}{c}3.89 \mathrm{E}-06 \\
(1.83 \mathrm{E}-06)\end{array}$ & $\begin{array}{l}1.92 \mathrm{E}-05 \\
(1.91 \mathrm{E}-06)\end{array}$ & $\begin{array}{l}2.06 \mathrm{E}-05 \\
(1.74 \mathrm{E}-06)\end{array}$ & $\begin{array}{c}1.41 \mathrm{E}-05 \\
(2.32 \mathrm{E}-06)\end{array}$ & $\begin{array}{c}1.47 \mathrm{E}-05 \\
(1.94 \mathrm{E}-06)\end{array}$ \\
\hline $\begin{array}{c}\text { Between immunized } \\
\text { hubs }\end{array}$ & $\begin{array}{c}0.153 \\
(0.010) \\
\end{array}$ & $\begin{array}{c}0.135 \\
(0.010) \\
\end{array}$ & $\begin{array}{c}0.141 \\
(0.010) \\
\end{array}$ & $\begin{array}{c}0.126 \\
(0.011) \\
\end{array}$ & $\begin{array}{c}0.299 \\
(0.013) \\
\end{array}$ & $\begin{array}{c}0.241 \\
(0.013) \\
\end{array}$ & $\begin{array}{c}0.282 \\
(0.013) \\
\end{array}$ & $\begin{array}{c}0.225 \\
(0.014) \\
\end{array}$ \\
\hline $\begin{array}{l}\text { Other immunized } \\
\text { alliance services }\end{array}$ & $\begin{array}{c}0.073 \\
(\mathbf{0 . 0 0 7 )}\end{array}$ & $\begin{array}{c}0.070 \\
(\mathbf{0 . 0 0 8 )}\end{array}$ & $\begin{array}{c}0.052 \\
(\mathbf{0 . 0 0 7 )} \\
\end{array}$ & $\begin{array}{c}0.054 \\
(0.008)\end{array}$ & $\begin{array}{c}0.167 \\
(0.009) \\
\end{array}$ & $\begin{array}{c}0.123 \\
(0.009)\end{array}$ & $\begin{array}{c}0.145 \\
(0.009) \\
\end{array}$ & $\begin{array}{c}0.086 \\
(0.009)\end{array}$ \\
\hline $\begin{array}{c}\text { Between competitors' } \\
\text { hubs }\end{array}$ & $\begin{array}{l}-0.009^{*} \\
(0.010)\end{array}$ & $\begin{array}{c}\text { 3.1E-04* } \\
(0.010)\end{array}$ & $\begin{array}{l}\text { 0.018* } \\
(0.010)\end{array}$ & $\begin{array}{c}0.029 \\
(0.011)\end{array}$ & $\begin{array}{c}0.030 \\
(0.012)\end{array}$ & $\begin{array}{l}-0.010^{*} \\
(0.012)\end{array}$ & $\begin{array}{c}0.051 \\
(0.012)\end{array}$ & $\begin{array}{l}0.004^{*} \\
(0.012)\end{array}$ \\
\hline $\begin{array}{l}\text { Other services to } \\
\text { immunized hubs }\end{array}$ & $\begin{array}{l}-0.105 \\
(0.008) \\
\end{array}$ & $\begin{array}{c}-0.121 \\
(0.008) \\
\end{array}$ & $\begin{array}{r}-0.050 \\
(0.008) \\
\end{array}$ & $\begin{array}{l}-0.055 \\
(0.009)\end{array}$ & $\begin{array}{l}-0.166 \\
(0.010) \\
\end{array}$ & $\begin{array}{l}-0.186 \\
(0.010) \\
\end{array}$ & $\begin{aligned}-0.099 \\
(0.012) \\
\end{aligned}$ & $\begin{array}{l}-0.103 \\
(0.012) \\
\end{array}$ \\
\hline Trade volume & $\begin{array}{c}9.67 \mathrm{E}-08 \\
(1.85 \mathrm{E}-07)\end{array}$ & $\begin{array}{c}5.82 \mathrm{E}-08 \\
(1.68 \mathrm{E}-07) \\
\end{array}$ & $\begin{array}{l}-4.02 \mathrm{E}-07 \\
(1.64 \mathrm{E}-07) \\
\end{array}$ & $\begin{array}{l}-6.88 \mathrm{E}-07 \\
(1.65 \mathrm{E}-07) \\
\end{array}$ & $\begin{array}{l}-1.05 \mathrm{E}-06 \\
(2.16 \mathrm{E}-07)\end{array}$ & $\begin{array}{l}-6.44 \mathrm{E}-07 \\
(1.95 \mathrm{E}-07)\end{array}$ & $\begin{array}{c}-1.68 \mathrm{E}-06 \\
(2.14 \mathrm{E}-07) \\
\end{array}$ & $\begin{array}{l}-1.16 \mathrm{E}-06 \\
(1.93 \mathrm{E}-07) \\
\end{array}$ \\
\hline Visa waiver & $\begin{array}{l}0.075^{*} \\
(0.030)\end{array}$ & $\begin{array}{l}0.076^{*} \\
(0.021)\end{array}$ & $\begin{array}{l}0.074 * \\
(0.028)\end{array}$ & $\begin{array}{c}0.055 \\
(0.021)\end{array}$ & $\begin{array}{l}0.035^{*} \\
(0.028)\end{array}$ & $\begin{array}{c}0.072 \\
(0.023)\end{array}$ & $\begin{array}{l}0.017^{*} \\
(0.027)\end{array}$ & $\begin{array}{c}0.050 \\
(0.023)\end{array}$ \\
\hline Open skies agreement & $\begin{array}{l}-0.013 \\
(0.007)\end{array}$ & $\begin{array}{c}0.008 \\
(0.007) \\
\end{array}$ & $\begin{array}{l}-0.016 \\
(0.009) \\
\end{array}$ & $\begin{array}{c}0.021 \\
(0.008)\end{array}$ & $\begin{array}{c}0.053 \\
(0.008) \\
\end{array}$ & $\begin{array}{c}0.062 \\
(0.008) \\
\end{array}$ & $\begin{array}{c}0.071 \\
(0.009) \\
\end{array}$ & $\begin{array}{c}0.084 \\
(0.009) \\
\end{array}$ \\
\hline \# of Observations & 51896 & 45923 & 37353 & 33242 & 51896 & 45923 & 37353 & 33242 \\
\hline Adjusted R-squared & 0.6442 & 0.6294 & 0.6136 & 0.5521 & 0.6644 & 0.6834 & 0.6428 & 0.6495 \\
\hline
\end{tabular}

Notes:

1. Heteroscedasticity consistent White standard errors reported in parentheses

2. Year, month, and airline dummies included in all regressions, but not reported

3. Star indicates lack of significance at 5\% level 
Table 3: Airline - airport-pair market fixed effects

\begin{tabular}{|c|c|c|c|c|c|c|c|c|}
\hline \multirow[b]{2}{*}{ Independent Variable } & \multicolumn{4}{|c|}{ Logarithm of frequency is dependent variable } & \multicolumn{4}{|c|}{ Logarithm of total passengers is dependent variable } \\
\hline & Entire sample & $\begin{array}{c}\text { Legacy } \\
\text { carriers only }\end{array}$ & $\begin{array}{l}\text { Excluding } \\
\text { UK }\end{array}$ & $\begin{array}{c}\text { Exclude UK, } \\
\text { legacy only }\end{array}$ & Entire sample & $\begin{array}{c}\text { Legacy } \\
\text { carriers only }\end{array}$ & $\begin{array}{c}\text { Excluding } \\
\text { UK }\end{array}$ & $\begin{array}{r}\text { Exclude UK, } \\
\text { legacy only }\end{array}$ \\
\hline Constant & $\begin{array}{c}2.7718 \\
(0.0654) \\
\end{array}$ & $\begin{array}{c}2.8987 \\
(0.0708) \\
\end{array}$ & $\begin{array}{c}3.6226 \\
(0.0941) \\
\end{array}$ & $\begin{array}{c}3.7700 \\
(0.1018) \\
\end{array}$ & $\begin{array}{c}7.7791 \\
0.0785() \\
\end{array}$ & $\begin{array}{c}7.8671 \\
(0.0838) \\
\end{array}$ & $\begin{array}{c}8.3763 \\
(0.0930) \\
\end{array}$ & $\begin{array}{c}8.5213 \\
(0.0981) \\
\end{array}$ \\
\hline HHI & $\begin{array}{c}0.0948 \\
(0.01268) \\
\end{array}$ & $\begin{array}{c}0.1178 \\
(0.0108) \\
\end{array}$ & $\begin{array}{c}0.1017 \\
(0.0127) \\
\end{array}$ & $\begin{array}{l}1.20 \mathrm{E}-01 \\
(0.0117) \\
\end{array}$ & $\begin{array}{c}0.1109 \\
(0.0128) \\
\end{array}$ & $\begin{array}{c}0.1499 \\
(0.0107) \\
\end{array}$ & $\begin{array}{c}0.1102 \\
(0.0126) \\
\end{array}$ & $\begin{array}{c}0.1436 \\
(0.0123) \\
\end{array}$ \\
\hline Average population & $\begin{array}{c}1.31 \mathrm{E}-07 \\
(1.23 \mathrm{E}-08)\end{array}$ & $\begin{array}{c}1.45 \mathrm{E}-07 \\
(1.29 \mathrm{E}-08)\end{array}$ & $\begin{array}{l}-1.20 \mathrm{E}-07 \\
(2.28 \mathrm{E}-08)\end{array}$ & $\begin{array}{l}-1.26 \mathrm{E}-07 \\
(2.40 \mathrm{E}-08)\end{array}$ & $\begin{array}{c}5.18 \mathrm{E}-08 \\
(1.50 \mathrm{E}-08)\end{array}$ & $\begin{array}{c}5.25 \mathrm{E}-08 \\
(1.62 \mathrm{E}-08)\end{array}$ & $\begin{array}{l}-1.43 \mathrm{E}-07 \\
(2.16 \mathrm{E}-08)\end{array}$ & $\begin{array}{l}-1.75 \mathrm{E}-07 \\
(2.35 \mathrm{E}-08)\end{array}$ \\
\hline $\begin{array}{l}\text { Average per capita } \\
\text { income }\end{array}$ & $\begin{array}{c}1.28 \mathrm{E}-05 \\
(1.32 \mathrm{E}-06)\end{array}$ & $\begin{array}{c}9.16 \mathrm{E}-06 \\
(1.24 \mathrm{E}-06)\end{array}$ & $\begin{array}{c}6.33 \mathrm{E}-06 \\
(1.48 \mathrm{E}-06)\end{array}$ & $\begin{array}{c}4.58 \mathrm{E}-06 \\
(1.54 \mathrm{E}-06)\end{array}$ & $\begin{array}{c}2.28 \mathrm{E}-05 \\
(1.41 \mathrm{E}-06)\end{array}$ & $\begin{array}{c}2.04 \mathrm{E}-05 \\
(1.43 \mathrm{E}-06)\end{array}$ & $\begin{array}{c}1.56 \mathrm{E}-05 \\
(1.54 \mathrm{E}-06)\end{array}$ & $\begin{array}{l}1.49 \mathrm{E}-05 \\
(1.62 \mathrm{E}-06)\end{array}$ \\
\hline $\begin{array}{c}\text { Between immunized } \\
\text { hubs }\end{array}$ & $\begin{array}{c}0.1289 \\
(0.0089) \\
\end{array}$ & $\begin{array}{c}0.1246 \\
(0.0087) \\
\end{array}$ & $\begin{array}{c}0.1403 \\
(0.0093) \\
\end{array}$ & $\begin{array}{c}0.1411 \\
(0.0091)\end{array}$ & $\begin{array}{c}0.2536 \\
(0.0120) \\
\end{array}$ & $\begin{array}{c}0.2405 \\
(0.0122) \\
\end{array}$ & $\begin{array}{c}0.2550 \\
(\mathbf{0 . 0 1 2 7}) \\
\end{array}$ & $\begin{array}{c}0.2468 \\
(0.0136) \\
\end{array}$ \\
\hline $\begin{array}{c}\text { Other immunized } \\
\text { alliance services }\end{array}$ & $\begin{array}{c}0.0111 \\
(0.0055)\end{array}$ & $\begin{array}{l}0.0052 * \\
(0.0057)\end{array}$ & $\begin{array}{c}0.0252 \\
(0.0065)\end{array}$ & $\begin{array}{c}0.0259 \\
(0.0066)\end{array}$ & $\begin{array}{c}0.0423 \\
(0.0064)\end{array}$ & $\begin{array}{c}0.0279 \\
(0.0065)\end{array}$ & $\begin{array}{c}0.0487 \\
(0.0070)\end{array}$ & $\begin{array}{c}0.0402 \\
(0.0070)\end{array}$ \\
\hline $\begin{array}{c}\text { Between competitors' } \\
\text { hubs }\end{array}$ & $\begin{array}{l}0.0130 * \\
(0.0099)\end{array}$ & $\begin{array}{l}\text { 0.0081* } \\
(0.0098)\end{array}$ & $\begin{array}{c}0.0319 \\
(0.0097)\end{array}$ & $\begin{array}{c}0.0346 \\
(0.0095)\end{array}$ & $\begin{array}{l}0.0105 * \\
(0.0113)\end{array}$ & $\begin{array}{l}-0.0069^{*} \\
(0.0105)\end{array}$ & $\begin{array}{l}\text { 0.0100* } \\
(0.0112)\end{array}$ & $\begin{array}{l}-0.0003^{*} \\
(0.0103)\end{array}$ \\
\hline $\begin{array}{l}\text { Other services to } \\
\text { immunized hubs }\end{array}$ & $\begin{array}{l}-0.0259 \\
(0.0059)\end{array}$ & $\begin{array}{l}-\mathbf{0 . 0 2 7 7} \\
(\mathbf{0 . 0 0 7 5 )}\end{array}$ & $\begin{array}{l}-0.0293 \\
(0.0061)\end{array}$ & $\begin{array}{l}-0.0298 \\
(0.0077)\end{array}$ & $\begin{array}{l}-0.0486 \\
(0.0074)\end{array}$ & $\begin{array}{l}-0.0511 \\
(0.0079)\end{array}$ & $\begin{array}{l}-0.0614 \\
(0.0083)\end{array}$ & $\begin{array}{l}-0.0596 \\
(0.0088)\end{array}$ \\
\hline Trade volume & $\begin{array}{l}-2.85 \mathrm{E}-07 \\
(1.33 \mathrm{E}-07)\end{array}$ & $\begin{array}{l}-8.42 \mathrm{E}-08^{*} \\
(1.23 \mathrm{E}-07) \\
\end{array}$ & $\begin{array}{l}-6.39 \mathrm{E}-07 \\
(1.54 \mathrm{E}-07)\end{array}$ & $\begin{array}{l}-8.04 \mathrm{E}-07 \\
(1.51 \mathrm{E}-07)\end{array}$ & $\begin{array}{l}-1.20 \mathrm{E}-06 \\
(1.70 \mathrm{E}-07)\end{array}$ & $\begin{array}{l}-1.04 \mathrm{E}-06 \\
(1.85 \mathrm{E}-07)\end{array}$ & $\begin{array}{l}-1.39 \mathrm{E}-06 \\
(1.72 \mathrm{E}-07)\end{array}$ & $\begin{array}{l}-1.55 \mathrm{E}-06 \\
(1.86 \mathrm{E}-07)\end{array}$ \\
\hline Visa waiver & $\begin{array}{c}0.1960 \\
(0.0206)\end{array}$ & $\begin{array}{c}0.1819 \\
(0.0207) \\
\end{array}$ & $\begin{array}{c}0.1790 \\
(0.0202)\end{array}$ & $\begin{array}{c}0.1661 \\
(0.0202) \\
\end{array}$ & $\begin{array}{c}0.1741 \\
(0.0253)\end{array}$ & $\begin{array}{c}0.1718 \\
(0.0244)\end{array}$ & $\begin{array}{c}0.1468 \\
(0.0245)\end{array}$ & $\begin{array}{c}0.1469 \\
(0.0234)\end{array}$ \\
\hline Open skies agreement & $\begin{array}{l}-0.0169 \\
(0.0058) \\
\end{array}$ & $\begin{array}{l}-0.0056^{*} \\
(0.0058) \\
\end{array}$ & $\begin{array}{l}-0.0035^{*} \\
(0.0073) \\
\end{array}$ & $\begin{array}{c}0.0150 \\
(0.0068) \\
\end{array}$ & $\begin{array}{c}0.0326 \\
(0.0054) \\
\end{array}$ & $\begin{array}{c}0.0395 \\
(0.0053) \\
\end{array}$ & $\begin{array}{c}0.0615 \\
(0.0070) \\
\end{array}$ & $\begin{array}{c}0.0705 \\
(0.0068) \\
\end{array}$ \\
\hline \# of Observations & 51896 & 45923 & 37353 & 33242 & 51896 & 45923 & 37353 & 33242 \\
\hline Adjusted R-squared & 0.81406 & 0.75943 & 0.76892 & 0.68249 & 0.83522 & 0.80975 & 0.80397 & 0.76148 \\
\hline
\end{tabular}

Notes:

1. Heteroscedasticity consistent White standard errors reported in parentheses

2. Year and month dummies included in all regressions, but not reported

3. Star indicates lack of significance at $5 \%$ level 
Table 4: Results for 'steady' services

\begin{tabular}{|c|c|c|c|c|c|c|c|c|}
\hline \multirow[b]{2}{*}{ Independent Variable } & \multicolumn{4}{|c|}{ Logarithm of frequency is dependent variable } & \multicolumn{4}{|c|}{ Logarithm of total passengers is dependent variable } \\
\hline & Entire sample & $\begin{array}{c}\text { Legacy } \\
\text { carriers only }\end{array}$ & $\begin{array}{l}\text { Excluding } \\
\text { UK }\end{array}$ & $\begin{array}{l}\text { Exclude UK, } \\
\text { legacy only }\end{array}$ & Entire sample & $\begin{array}{c}\text { Legacy } \\
\text { carriers only }\end{array}$ & $\begin{array}{c}\text { Excluding } \\
\text { UK }\end{array}$ & $\begin{array}{r}\text { Exclude UK, } \\
\text { legacy only }\end{array}$ \\
\hline Constant & $\begin{array}{c}1.9367 \\
(0.0707) \\
\end{array}$ & $\begin{array}{c}1.8163 \\
(0.0728) \\
\end{array}$ & $\begin{array}{c}1.6271 \\
(0.0982) \\
\end{array}$ & $\begin{array}{c}1.7221 \\
(0.1008) \\
\end{array}$ & $\begin{array}{c}7.0183 \\
(0.0926) \\
\end{array}$ & $\begin{array}{c}6.8522 \\
(0.0959) \\
\end{array}$ & $\begin{array}{c}6.5029 \\
(0.1185) \\
\end{array}$ & $\begin{array}{c}6.5661 \\
(0.1145) \\
\end{array}$ \\
\hline HHI & $\begin{array}{c}0.0737 \\
(0.0116) \\
\end{array}$ & $\begin{array}{c}0.0667 \\
(0.0117) \\
\end{array}$ & $\begin{array}{c}0.0804 \\
(0.0121) \\
\end{array}$ & $\begin{array}{c}0.0738 \\
(0.0124) \\
\end{array}$ & $\begin{array}{c}0.1020 \\
(0.0139) \\
\end{array}$ & $\begin{array}{c}0.0972 \\
(0.0139) \\
\end{array}$ & $\begin{array}{c}0.1087 \\
(0.0155) \\
\end{array}$ & $\begin{array}{c}0.1055 \\
(0.0156) \\
\end{array}$ \\
\hline Average population & $\begin{array}{c}.00 \mathrm{E}-07 \\
(1.03 \mathrm{E}-08)\end{array}$ & $\begin{array}{c}3.37 \mathrm{E}-07 \\
(1.09 \mathrm{E}-08)\end{array}$ & $\begin{array}{c}4.33 \mathrm{E}-07 \\
(1.90 \mathrm{E}-08)\end{array}$ & $\begin{array}{c}4.20 \mathrm{E}-07 \\
(1.97 \mathrm{E}-08)\end{array}$ & $\begin{array}{c}2.24 \mathrm{E}-07 \\
(1.40 \mathrm{E}-08)\end{array}$ & $\begin{array}{c}2.67 \mathrm{E}-07 \\
(1.49 \mathrm{E}-08)\end{array}$ & $\begin{array}{c}3.70 \mathrm{E}-07 \\
(2.15 \mathrm{E}-08)\end{array}$ & $\begin{array}{c}3.61 \mathrm{E}-07 \\
(2.11 \mathrm{E}-08)\end{array}$ \\
\hline $\begin{array}{l}\text { Average per capita } \\
\text { income }\end{array}$ & $\begin{array}{c}2.08 \mathrm{E}-05 \\
(8.94 \mathrm{E}-07)\end{array}$ & $\begin{array}{c}2.14 \mathrm{E}-05 \\
(8.92 \mathrm{E}-07)\end{array}$ & $\begin{array}{c}2.39 \mathrm{E}-05 \\
(1.39 \mathrm{E}-06)\end{array}$ & $\begin{array}{c}2.29 \mathrm{E}-05 \\
(1.40 \mathrm{E}-06)\end{array}$ & $\begin{array}{c}3.35 \mathrm{E}-05 \\
(1.20 \mathrm{E}-06)\end{array}$ & $\begin{array}{c}3.46 \mathrm{E}-05 \\
(1.20 \mathrm{E}-06)\end{array}$ & $\begin{array}{c}3.57 \mathrm{E}-05 \\
(1.70 \mathrm{E}-06)\end{array}$ & $\begin{array}{c}3.50 \mathrm{E}-05 \\
(1.64 \mathrm{E}-06)\end{array}$ \\
\hline $\begin{array}{c}\text { Between immunized } \\
\text { hubs }\end{array}$ & $\begin{array}{c}0.1484 \\
(0.0112) \\
\end{array}$ & $\begin{array}{c}0.1541 \\
(0.0115) \\
\end{array}$ & $\begin{array}{c}0.1730 \\
(0.0145) \\
\end{array}$ & $\begin{array}{c}0.1823 \\
(0.0152) \\
\end{array}$ & $\begin{array}{c}0.2211 \\
(0.0116) \\
\end{array}$ & $\begin{array}{c}0.2244 \\
(0.0119) \\
\end{array}$ & $\begin{array}{c}0.2300 \\
(0.0138) \\
\end{array}$ & $\begin{array}{c}0.2352 \\
(0.0146) \\
\end{array}$ \\
\hline $\begin{array}{c}\text { Other immunized } \\
\text { alliance services }\end{array}$ & $\begin{array}{l}\text { 0.0040* } \\
(0.0064)\end{array}$ & $\begin{array}{l}0.0022 * \\
(0.0064)\end{array}$ & $\begin{array}{c}0.0182 \\
(0.0073)\end{array}$ & $\begin{array}{c}0.0239 \\
(0.0073)\end{array}$ & $\begin{array}{c}0.0333 \\
(0.0074)\end{array}$ & $\begin{array}{c}0.0295 \\
(0.0073)\end{array}$ & $\begin{array}{c}0.0404 \\
(0.0084)\end{array}$ & $\begin{array}{c}0.0432 \\
(0.0084) \\
\end{array}$ \\
\hline $\begin{array}{c}\text { Between competitors' } \\
\text { hubs }\end{array}$ & $\begin{array}{c}-0.0743 \\
(0.0096) \\
\end{array}$ & $\begin{array}{c}-\mathbf{- 0 . 0 7 1 7} \\
(\mathbf{0 . 0 0 9 6 )} \\
\end{array}$ & $\begin{array}{l}-0.0469 \\
(0.0117) \\
\end{array}$ & $\begin{array}{c}-0.0388 \\
(0.0122) \\
\end{array}$ & $\begin{array}{c}-0.0604 \\
(0.0115) \\
\end{array}$ & $\begin{array}{l}-0.0610 \\
(0.0115) \\
\end{array}$ & $\begin{array}{ll}-0.0575 \\
(0.0125) \\
\end{array}$ & $\begin{array}{c}-\mathbf{- 0 . 0 5 4 3} \\
(\mathbf{0 . 0 1 3 0 )} \\
\end{array}$ \\
\hline $\begin{array}{l}\text { Other services to } \\
\text { immunized hubs }\end{array}$ & $\begin{array}{l}-0.0462 \\
(0.0084)\end{array}$ & $\begin{array}{l}-0.0612 \\
(0.0090)\end{array}$ & $\begin{array}{l}-0.0445 \\
(0.0115)\end{array}$ & $\begin{array}{l}-0.0555 \\
(0.0119)\end{array}$ & $\begin{array}{l}-0.0691 \\
(0.0078)\end{array}$ & $\begin{array}{l}-0.0857 \\
(0.0083)\end{array}$ & $\begin{array}{l}-0.0694 \\
(0.0119)\end{array}$ & $\begin{array}{l}-0.0825 \\
(0.0126)\end{array}$ \\
\hline Trade volume & $\begin{array}{c}1.12 \mathrm{E}-06 \\
(1.43 \mathrm{E}-07)\end{array}$ & $\begin{array}{c}1.05 \mathrm{E}-06 \\
(1.42 \mathrm{E}-07)\end{array}$ & $\begin{array}{c}1.21 \mathrm{E}-06 \\
(1.74 \mathrm{E}-07)\end{array}$ & $\begin{array}{c}1.01 \mathrm{E}-06 \\
(1.83 \mathrm{E}-07)\end{array}$ & $\begin{array}{l}-1.22 \mathrm{E}-06 \\
(1.63 \mathrm{E}-07)\end{array}$ & $\begin{array}{l}-1.25 \mathrm{E}-06 \\
(1.66 \mathrm{E}-07)\end{array}$ & $\begin{array}{l}-9.60 \mathrm{E}-07 \\
(1.62 \mathrm{E}-07)\end{array}$ & $\begin{array}{l}-1.09 \mathrm{E}-06 \\
(1.65 \mathrm{E}-07)\end{array}$ \\
\hline Visa waiver & $\begin{array}{c}0.3435 \\
(0.0342) \\
\end{array}$ & $\begin{array}{c}0.3502 \\
(0.0344)\end{array}$ & $\begin{array}{c}0.3782 \\
(0.0349) \\
\end{array}$ & $\begin{array}{c}0.3758 \\
(0.0349) \\
\end{array}$ & $\begin{array}{c}0.3263 \\
(0.0312)\end{array}$ & $\begin{array}{c}0.3347 \\
(0.0314)\end{array}$ & $\begin{array}{c}0.3498 \\
(0.0322)\end{array}$ & $\begin{array}{c}0.3493 \\
(0.0321)\end{array}$ \\
\hline Open skies agreement & $\begin{array}{l}0.0132 * \\
(0.0073) \\
\end{array}$ & $\begin{array}{l}0.0091^{*} \\
(0.0076) \\
\end{array}$ & $\begin{array}{c}0.0476 \\
(0.0103) \\
\end{array}$ & $\begin{array}{c}0.0433 \\
(0.0104) \\
\end{array}$ & $\begin{array}{c}0.0496 \\
(0.0087) \\
\end{array}$ & $\begin{array}{c}0.0465 \\
(0.0089) \\
\end{array}$ & $\begin{array}{c}0.0831 \\
(0.0108) \\
\end{array}$ & $\begin{array}{c}0.0790 \\
(0.0110) \\
\end{array}$ \\
\hline \# of Observations & 18862 & 18461 & 11791 & 11593 & 18862 & 18461 & 11791 & 11593 \\
\hline Adjusted R-squared & 0.8028 & 0.79314 & 0.66465 & 0.66237 & 0.84585 & 0.84353 & 0.78110 & 0.78439 \\
\hline
\end{tabular}

Notes:

1. Sample includes only those airline-market cross-sections, which appear in the data at least for 190 months (out of 204 maximum possible)

2. Number of cross-sections: entire sample - 93; legacy carriers only - 91; exclude UK - 58; legacy carriers and excluding UK - 57.

3. Model employed - airline - market fixed effects.

4. Heteroscedasticity consistent White standard errors reported in parentheses.

5. Year and month dummies included in all regressions, but not reported.

6. Star indicates lack of significance at $5 \%$ level 
Table 5: Dynamic panel data GMM model results

\begin{tabular}{|c|c|c|c|c|c|c|c|c|}
\hline \multirow[b]{2}{*}{ Independent Variable } & \multicolumn{4}{|c|}{ Logarithm of frequency is dependent variable } & \multicolumn{4}{|c|}{ Logarithm of total passengers is dependent variable } \\
\hline & Entire sample & $\begin{array}{c}\text { Legacy } \\
\text { carriers only }\end{array}$ & $\begin{array}{c}\text { Excluding } \\
\text { UK }\end{array}$ & $\begin{array}{l}\text { Exclude UK, } \\
\text { legacy only }\end{array}$ & Entire sample & $\begin{array}{c}\text { Legacy } \\
\text { carriers only }\end{array}$ & $\begin{array}{c}\text { Excluding } \\
\text { UK }\end{array}$ & $\begin{array}{r}\text { Exclude UK, } \\
\text { legacy only }\end{array}$ \\
\hline HHI & $\begin{array}{c}0.0473 \\
(0.0030) \\
\end{array}$ & $\begin{array}{c}0.0639 \\
(0.00146) \\
\end{array}$ & $\begin{array}{c}0.0549 \\
(0.0020) \\
\end{array}$ & $\begin{array}{c}0.0723 \\
(0.0011) \\
\end{array}$ & $\begin{array}{c}0.0639 \\
(0.0035) \\
\end{array}$ & $\begin{array}{c}0.0889 \\
(0.0017) \\
\end{array}$ & $\begin{array}{c}0.0606 \\
(0.0028) \\
\end{array}$ & $\begin{array}{c}0.0873 \\
(0.0018) \\
\end{array}$ \\
\hline Average population & $\begin{array}{c}7.59 \mathrm{E}-08 \\
(2.43 \mathrm{E}-09) \\
\end{array}$ & $\begin{array}{c}8.31 \mathrm{E}-08 \\
(1.48 \mathrm{E}-09)\end{array}$ & $\begin{array}{c}-5.88 \mathrm{E}-08 \\
(4.61 \mathrm{E}-09) \\
\end{array}$ & $\begin{array}{l}-6.61 \mathrm{E}-08 \\
(3.56 \mathrm{E}-09) \\
\end{array}$ & $\begin{array}{c}4.16 \mathrm{E}-08 \\
(3.18 \mathrm{E}-09)\end{array}$ & $\begin{array}{c}4.00 \mathrm{E}-08 \\
(1.29 \mathrm{E}-09)\end{array}$ & $\begin{array}{l}-7.26 \mathrm{E}-08 \\
(6.63 \mathrm{E}-09) \\
\end{array}$ & $\begin{array}{l}-9.46 \mathrm{E}-08 \\
(5.13 \mathrm{E}-09) \\
\end{array}$ \\
\hline $\begin{array}{l}\text { Average per capita } \\
\text { income }\end{array}$ & $\begin{array}{c}6.88 \mathrm{E}-06 \\
(3.98 \mathrm{E}-07)\end{array}$ & $\begin{array}{c}5.43 \mathrm{E}-06 \\
(2.47 \mathrm{E}-07)\end{array}$ & $\begin{array}{c}3.45 \mathrm{E}-06 \\
(3.48 \mathrm{E}-07)\end{array}$ & $\begin{array}{l}3.16 \mathrm{E}-06 \\
(2.36 \mathrm{E}-07)\end{array}$ & $\begin{array}{c}1.35 \mathrm{E}-05 \\
(5.89 \mathrm{E}-07)\end{array}$ & $\begin{array}{l}1.24 \mathrm{E}-05 \\
(2.74 \mathrm{E}-07)\end{array}$ & $\begin{array}{c}9.70 \mathrm{E}-06 \\
(5.15 \mathrm{E}-07)\end{array}$ & $\begin{array}{l}8.72 \mathrm{E}-06 \\
(4.26 \mathrm{E}-07)\end{array}$ \\
\hline $\begin{array}{c}\text { Between immunized } \\
\text { hubs }\end{array}$ & $\begin{array}{c}0.0726 \\
(0.0034) \\
\end{array}$ & $\begin{array}{c}0.0691 \\
(0.0022)\end{array}$ & $\begin{array}{c}0.0805 \\
(0.0025) \\
\end{array}$ & $\begin{array}{c}0.0840 \\
(0.0019) \\
\end{array}$ & $\begin{array}{c}\mathbf{0 . 1 3 9 7} \\
(\mathbf{0 . 0 0 5 3 )} \\
\end{array}$ & $\begin{array}{c}0.1358 \\
(0.0023) \\
\end{array}$ & $\begin{array}{c}0.1405 \\
(0.0034) \\
\end{array}$ & $\begin{array}{c}0.1382 \\
(0.0017) \\
\end{array}$ \\
\hline $\begin{array}{c}\text { Other immunized } \\
\text { alliance services }\end{array}$ & $\begin{array}{c}0.0115 \\
(0.0014) \\
\end{array}$ & $\begin{array}{c}0.0062 \\
(0.0008) \\
\end{array}$ & $\begin{array}{c}0.0188 \\
(0.0011) \\
\end{array}$ & $\begin{array}{c}\mathbf{0 . 0 1 8 7} \\
(\mathbf{0 . 0 0 0 8 )} \\
\end{array}$ & $\begin{array}{c}0.0281 \\
(0.0020) \\
\end{array}$ & $\begin{array}{c}\mathbf{0 . 0 1 9 7} \\
(\mathbf{0 . 0 0 0 7 )} \\
\end{array}$ & $\begin{array}{c}0.0312 \\
(0.0016) \\
\end{array}$ & $\begin{array}{c}0.0272 \\
(\mathbf{0 . 0 0 1 2}) \\
\end{array}$ \\
\hline $\begin{array}{c}\text { Between competitors' } \\
\text { hubs }\end{array}$ & $\begin{array}{c}0.0156 \\
(0.0018)\end{array}$ & $\begin{array}{c}0.0100 \\
(0.0014)\end{array}$ & $\begin{array}{c}0.0238 \\
(0.0020)\end{array}$ & $\begin{array}{c}0.0254 \\
(0.0012) \\
\end{array}$ & $\begin{array}{c}0.0136 \\
(0.0036)\end{array}$ & $\begin{array}{l}-0.0002^{*} \\
(0.0018)\end{array}$ & $\begin{array}{c}0.0092 \\
(0.0022)\end{array}$ & $\begin{array}{c}0.0036 \\
(0.0014) \\
\end{array}$ \\
\hline $\begin{array}{l}\text { Other services to } \\
\text { immunized hubs }\end{array}$ & \begin{tabular}{|l|}
-0.0079 \\
$(0.0014)$ \\
\end{tabular} & \begin{tabular}{|c|}
-0.0109 \\
$(0.0010)$ \\
\end{tabular} & \begin{tabular}{|c|}
$\mathbf{- 0 . 0 1 1 8}$ \\
$(\mathbf{0 . 0 0 1 2 )}$ \\
\end{tabular} & $\begin{array}{c}-0.0151 \\
(0.0010) \\
\end{array}$ & $\begin{array}{c}-0.0267 \\
(\mathbf{0 . 0 0 2 3 )} \\
\end{array}$ & $\begin{array}{l}-0.0284 \\
(0.0012) \\
\end{array}$ & $\begin{aligned}-0.0355 \\
(\mathbf{0 . 0 0 1 8 )} \\
\end{aligned}$ & $\begin{array}{c}-0.0340 \\
(0.0012) \\
\end{array}$ \\
\hline Trade volume & $\begin{array}{l}-6.33 \mathrm{E}-08^{*} \\
(5.26 \mathrm{E}-08) \\
\end{array}$ & $\begin{array}{l}1.36 \mathrm{E}-08 * \\
(2.93 \mathrm{E}-08) \\
\end{array}$ & $\begin{array}{c}-2.45 \mathrm{E}-07 \\
(3.42 \mathrm{E}-08) \\
\end{array}$ & $\begin{array}{l}-4.23 \mathrm{E}-07 \\
(3.04 \mathrm{E}-08) \\
\end{array}$ & $\begin{array}{l}-5.02 \mathrm{E}-07 \\
(6.61 \mathrm{E}-08) \\
\end{array}$ & $\begin{array}{l}-4.72 \mathrm{E}-07 \\
(3.67 \mathrm{E}-08)\end{array}$ & $\begin{array}{l}-6.53 \mathrm{E}-07 \\
(5.65 \mathrm{E}-08) \\
\end{array}$ & $\begin{array}{l}-7.55 \mathrm{E}-07 \\
(3.61 \mathrm{E}-08) \\
\end{array}$ \\
\hline Visa waiver & $\begin{array}{c}0.0976 \\
(0.0031)\end{array}$ & $\begin{array}{c}0.0967 \\
(0.00204)\end{array}$ & $\begin{array}{c}0.0946 \\
(0.0022)\end{array}$ & $\begin{array}{c}0.0947 \\
(0.0016)\end{array}$ & $\begin{array}{c}0.0968 \\
(0.0092)\end{array}$ & $\begin{array}{c}0.1089 \\
(0.0051)\end{array}$ & $\begin{array}{c}0.0882 \\
(0.0042)\end{array}$ & $\begin{array}{c}0.0944 \\
(0.0039)\end{array}$ \\
\hline Open skies agreement & $\begin{array}{l}-0.0087 \\
(0.0010) \\
\end{array}$ & $\begin{array}{l}-0.0016^{*} \\
(0.0009) \\
\end{array}$ & $\begin{array}{l}-0.0011 \\
(0.0014) \\
\end{array}$ & $\begin{array}{c}0.0093 \\
(0.0010) \\
\end{array}$ & $\begin{array}{c}0.0173 \\
(0.0019) \\
\end{array}$ & $\begin{array}{c}0.0226 \\
(0.0012) \\
\end{array}$ & $\begin{array}{c}0.0344 \\
(0.0019) \\
\end{array}$ & $\begin{array}{c}0.0429 \\
(0.0014) \\
\end{array}$ \\
\hline \# of Observations & 47610 & 42838 & 34354 & 30954 & 47610 & 42838 & 34354 & 30954 \\
\hline $\begin{array}{c}\text { P-value of Hansen J } \\
\text { statistic }\end{array}$ & 0.0311 & 0.2802 & 0.8484 & 0.9836 & 0.0205 & 0.1192 & 0.7180 & 0.9892 \\
\hline
\end{tabular}

Notes:

1. Each specification includes first and second lag of the dependent variable

2. Model employed - dynamic panel data GMM (Arellano and Bover, 1995) with airline-market fixed effects

3. Year and month fixed effects included in all regressions, but not reported

4. Heteroscedasticity consistent White standard errors reported in parentheses

5. Star indicates lack of significance at $5 \%$ level 
Table 6: Effects on aircraft size and load factors

(a) Airline-market fixed effects

\begin{tabular}{|c|c|c|c|c|c|}
\hline \multicolumn{2}{|c|}{ Specification } & $\begin{array}{c}\text { Between } \\
\text { immunized hubs }\end{array}$ & $\begin{array}{l}\text { Other immunized } \\
\text { alliance services }\end{array}$ & $\begin{array}{c}\text { Between } \\
\text { competitors' hubs }\end{array}$ & $\begin{array}{l}\text { Other services to } \\
\text { immunized hubs }\end{array}$ \\
\hline \multirow{4}{*}{$\begin{array}{c}\text { Dependent } \\
\text { variable - } \\
\text { logarithm of } \\
\text { aircraft size }\end{array}$} & Entire sample & $\begin{array}{l}0.0089 * \\
(0.0056)\end{array}$ & $\begin{array}{c}0.0159 \\
(0.0031)\end{array}$ & $\begin{array}{l}-0.0346 \\
(0.0052)\end{array}$ & $\begin{array}{l}-0.0066 \\
(0.0034)\end{array}$ \\
\hline & $\begin{array}{c}\text { Legacy carriers } \\
\text { only }\end{array}$ & $\begin{array}{l}0.0082 * \\
(0.0055) \\
\end{array}$ & $\begin{array}{c}0.0141 \\
(0.0031) \\
\end{array}$ & $\begin{array}{l}-0.0359 \\
(0.0052) \\
\end{array}$ & $\begin{array}{l}-0.0011^{*} \\
(0.0041)\end{array}$ \\
\hline & Excluding UK & $\begin{array}{l}0.0053 * \\
(0.0057)\end{array}$ & $\begin{array}{l}0.0018 * \\
(0.0038)\end{array}$ & $\begin{array}{l}-0.0432 \\
(0.0059)\end{array}$ & $\begin{array}{l}-0.0057 * \\
(0.0042)\end{array}$ \\
\hline & $\begin{array}{l}\text { Excluding UK, } \\
\text { legacy only }\end{array}$ & $\begin{array}{l}0.0044^{*} \\
(0.0057)\end{array}$ & $\begin{array}{l}-0.0011^{*} \\
(0.0039)\end{array}$ & $\begin{array}{l}-0.0450 \\
(0.0059)\end{array}$ & $\begin{array}{l}0.0002 * \\
(0.0051)\end{array}$ \\
\hline \multirow{4}{*}{$\begin{array}{c}\text { Dependent } \\
\text { variable - } \\
\text { logarithm of } \\
\text { load factor }\end{array}$} & Entire sample & $\begin{array}{c}0.1247 \\
(0.0124)\end{array}$ & $\begin{array}{c}0.0311 \\
(0.0040)\end{array}$ & $\begin{array}{l}-0.0024^{*} \\
(0.0066)\end{array}$ & $\begin{array}{l}-0.0227 \\
(0.0049)\end{array}$ \\
\hline & $\begin{array}{c}\text { Legacy carriers } \\
\text { only } \\
\end{array}$ & $\begin{array}{c}0.1158 \\
(0.0128) \\
\end{array}$ & $\begin{array}{c}0.0226 \\
(0.0040) \\
\end{array}$ & $\begin{array}{l}-0.0151 \\
(0.0065) \\
\end{array}$ & $\begin{array}{c}-0.0234 \\
(0.0053) \\
\end{array}$ \\
\hline & Excluding UK & $\begin{array}{c}0.1146 \\
(0.0126)\end{array}$ & $\begin{array}{c}0.0235 \\
(0.0046)\end{array}$ & $\begin{array}{l}-0.0219 \\
(0.0067)\end{array}$ & $\begin{array}{l}-0.0320 \\
(0.0055)\end{array}$ \\
\hline & $\begin{array}{l}\text { Excluding UK, } \\
\text { legacy only }\end{array}$ & $\begin{array}{c}0.1056 \\
(0.0135)\end{array}$ & $\begin{array}{c}0.0143 \\
(0.0049)\end{array}$ & $\begin{array}{l}-0.0349 \\
(0.0069)\end{array}$ & $\begin{array}{l}-0.0298 \\
(0.0061)\end{array}$ \\
\hline
\end{tabular}

Notes:

1. All dependent variables, specifications, and sample sizes are identical to those reported in Table 3

2. Adjusted R-squared and coefficients on control variables are similar to those reported in Table 3

3. Heteroscedasticity consistent White standard errors reported in parentheses

4. Star indicates lack of significance at $5 \%$ level

(b) Dynamic panel data GMM

\begin{tabular}{|c|c|c|c|c|c|}
\hline \multicolumn{2}{|c|}{ Specification } & $\begin{array}{c}\text { Between } \\
\text { immunized hubs }\end{array}$ & $\begin{array}{l}\text { Other immunized } \\
\text { alliance services }\end{array}$ & $\begin{array}{c}\text { Between } \\
\text { competitors' hubs }\end{array}$ & $\begin{array}{l}\text { Other services to } \\
\text { immunized hubs }\end{array}$ \\
\hline \multirow{4}{*}{$\begin{array}{l}\text { Dependent } \\
\text { variable - } \\
\text { logarithm of } \\
\text { aircraft size }\end{array}$} & Entire sample & $\begin{array}{l}0.0012 * \\
(0.0007) \\
\end{array}$ & $\begin{array}{c}0.0058 \\
(0.0003) \\
\end{array}$ & $\begin{array}{l}-0.0100 \\
(0.0006) \\
\end{array}$ & $\begin{array}{l}-0.0044 \\
(0.0005) \\
\end{array}$ \\
\hline & $\begin{array}{c}\text { Legacy carriers } \\
\text { only }\end{array}$ & $\begin{array}{l}-0.0004^{*} \\
(0.0003)\end{array}$ & $\begin{array}{c}0.0047 \\
(0.0001)\end{array}$ & $\begin{array}{l}-0.0103 \\
(0.0002)\end{array}$ & $\begin{array}{l}-0.0029 \\
(0.0002)\end{array}$ \\
\hline & Excluding UK & $\begin{array}{l}0.0002 * \\
(0.0004)\end{array}$ & $\begin{array}{c}0.0021 \\
(0.0002)\end{array}$ & $\begin{array}{l}-0.0112 \\
(0.0003)\end{array}$ & $\begin{array}{l}-0.0022 \\
(0.0003)\end{array}$ \\
\hline & $\begin{array}{c}\text { Excluding UK, } \\
\text { legacy only }\end{array}$ & $\begin{array}{l}0.0001^{*} \\
(0.0004)\end{array}$ & $\begin{array}{c}0.0010 \\
(0.0003)\end{array}$ & $\begin{array}{l}-0.0121 \\
(0.0004)\end{array}$ & $\begin{array}{l}-0.0008 \\
(0.0002)\end{array}$ \\
\hline \multirow{4}{*}{$\begin{array}{c}\text { Dependent } \\
\text { variable - } \\
\text { logarithm of } \\
\text { load factor }\end{array}$} & Entire sample & $\begin{array}{c}0.0578 \\
(0.0024)\end{array}$ & $\begin{array}{c}0.0170 \\
(0.0007)\end{array}$ & $\begin{array}{l}0.0001 * \\
(0.0015)\end{array}$ & $\begin{array}{l}-0.0149 \\
(0.0011)\end{array}$ \\
\hline & $\begin{array}{c}\text { Legacy carriers } \\
\text { only }\end{array}$ & $\begin{array}{c}0.0502 \\
(0.0013)\end{array}$ & $\begin{array}{c}0.0117 \\
(0.0004)\end{array}$ & $\begin{array}{l}-0.0078 \\
(0.0007)\end{array}$ & $\begin{array}{l}-0.0152 \\
(0.0005)\end{array}$ \\
\hline & Excluding UK & $\begin{array}{c}0.0490 \\
(0.0015)\end{array}$ & $\begin{array}{c}0.0124 \\
(0.0006)\end{array}$ & $\begin{array}{l}-0.0110 \\
(0.0010)\end{array}$ & $\begin{array}{l}-0.0190 \\
(0.0007)\end{array}$ \\
\hline & $\begin{array}{l}\text { Excluding UK, } \\
\text { legacy only }\end{array}$ & $\begin{array}{c}0.0425 \\
(0.0008)\end{array}$ & $\begin{array}{c}0.0073 \\
(0.0004)\end{array}$ & $\begin{array}{l}-0.0176 \\
(0.0006)\end{array}$ & $\begin{array}{l}-0.0178 \\
(0.0006)\end{array}$ \\
\hline
\end{tabular}

Notes:

5. All dependent variables, specifications, and sample sizes are identical to those reported in Table 5

6. P-values of Hansen statistic and coefficients on control variables are similar to those reported in Table 5

7. Heteroscedasticity consistent White standard errors reported in parentheses

8. Star indicates lack of significance at $5 \%$ level 


\section{Appendix}

\section{Timeline of Antitrust Immunity Granting Decisions on the Transatlantic Market:}

January 13, 1993, Antitrust immunity involving KLM Royal Dutch Airlines and Northwest Airlines

May 20, 1996, United Airlines - Lufthansa pair granted antitrust immunity

June 14, 1996, Antitrust immunity granted to the following three pairs:

- Delta Air Lines - Swissair (the partnership ended on August 5, 2000)

- Delta Air Lines - Sabena (the partnership ended on August 5, 2000)

- Delta Air Lines - Austrian Airlines (the partnership ended on March 25, 2000)

Carve-outs: ATL-BRU, ATL-ZRH, CVG-ZRH

November 1, 1996, United - SAS receives antitrust immunity

December 3, 1999, Northwest - Alitalia granted immunity. The partnership ended in 2000

May 11, 2000, Antitrust immunity is granted to the following pairs:

- American Airlines - Swissair (ended following Swissair bankruptcy on March 31, 2002)

- American Airlines - Sabena (ended upon Sabena bankruptcy on November 7, 2001)

January 26, 2001, United - Austrian, and United - Lauda granted antitrust immunity

January 18, 2002, Antitrust immunity granted to the following pairs of carriers:

- Delta Air Lines - Air France

- Delta Air Lines - Alitalia

- Delta Air Lines - Czech Airlines

April 4, 2002, Antitrust immunity granted to United Airlines - British Midland (BMI), conditional on open-skies agreement between US and UK within the next six months

July 30, 2002, Antitrust immunity granted to American Airlines - Finnair

November 22, 2002, Antitrust immunity granted to American Airlines - Swiss International

Airlines (ended in 2005)

April 15, 2004, Antitrust immunity granted to American Airlines - SN Brussels Airlines

February 13, 2007, First multi-airline antitrust immunity granted to the alliance consisting of United Airlines and the following EU partners: Austrian, BMI, Lot Polish Airlines, Lufthansa, SAS, Swiss, and TAP Air Portugal (all members of Star Alliance)

May 22, 2008, Six-way antitrust immunity granted to the following members of Skyteam Alliance: Delta, Northwest, Alitalia, Czech, KLM, Air France. Note that same airlines' first application for six-way immunity was denied on February 6, 2006 